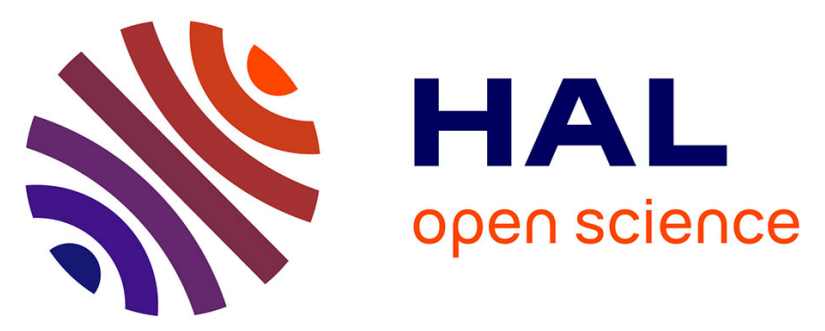

\title{
Surfactant- and Binder-Free Hierarchical Platinum Nanoarrays Directly Grown onto a Carbon Felt Electrode for Efficient Electrocatalysis
}

Widya Ernayati Kosimaningrum, Thi Xuan Huong Le, Yaovi Holade, Mikhael Bechelany, Sophie Tingry, Buchari Buchari, Indra Noviandri, Christophe Innocent, Marc Cretin

\section{To cite this version:}

Widya Ernayati Kosimaningrum, Thi Xuan Huong Le, Yaovi Holade, Mikhael Bechelany, Sophie Tingry, et al.. Surfactant- and Binder-Free Hierarchical Platinum Nanoarrays Directly Grown onto a Carbon Felt Electrode for Efficient Electrocatalysis. ACS Applied Materials \& Interfaces, 2017, 9 (27), pp.22476 - 22489. 10.1021/acsami.7b04651 . hal-01680945

\section{HAL Id: hal-01680945 https://hal.science/hal-01680945}

Submitted on 9 Jun 2021

HAL is a multi-disciplinary open access archive for the deposit and dissemination of scientific research documents, whether they are published or not. The documents may come from teaching and research institutions in France or abroad, or from public or private research centers.
L'archive ouverte pluridisciplinaire HAL, est destinée au dépôt et à la diffusion de documents scientifiques de niveau recherche, publiés ou non, émanant des établissements d'enseignement et de recherche français ou étrangers, des laboratoires publics ou privés. 


\section{Surfactant- and Binder-Free Hierarchical Platinum}

\section{Nanoarrays Directly Grown onto a Carbon Felt \\ Electrode for Efficient Electrocatalysis}

Widya Ernayati Kosimaningrum ${ }^{\mathrm{a}, \mathrm{b}, \mathrm{c}}$, Thi Xuan Huong Le ${ }^{\mathrm{a}, \mathrm{d}}$, Yaovi Holade ${ }^{\mathrm{a}}$, Mikhael Bechelany ${ }^{\mathrm{a}}$, Sophie Tingry ${ }^{\mathrm{a}}$, Buchari Buchari ${ }^{\mathrm{b}}$, Indra Noviandri ${ }^{\mathrm{b}}$, Christophe Innocent $^{\mathrm{a}^{*}}$, Marc Cretin ${ }^{\mathrm{a}^{*}}$

${ }^{a}$ Institut Européen des Membranes, IEM UMR 5635, CNRS-UM-ENSCM, Place Eugène

Bataillon CC 047, 34095 Montpellier, Cedex 5, France.

b Analytical Chemistry Division, Faculty of Mathematics and Natural Sciences, Institut Teknologi Bandung, Jl. Ganesha 10, Bandung 40132, Indonesia.

${ }^{c}$ Department of Chemical Engineering, Sultan Ageng Tirtayasa University, Jl. Jend. Sudirman KM 3, Cilegon, Banten, Indonesia

${ }^{d}$ Van Lang University, 45 Nguyen Khac Nhu, District 1, Ho Chi Minh City, Vietnam.

KEYWORDS. platinum, electrodeposition, oxygen reduction reaction, air-breathing cathode, microbial fuel cell.

ABSTRACT: The future of fuel cells that convert the chemical energy to electricity relies mostly on the efficiency of oxygen reduction reaction (ORR) due to its sluggish kinetics. By 
effectively bypassing the use of organic surfactants, post-synthesis steps for the immobilization onto electrodes, the catalytic inks preparation using binders, and the common problem of nanoparticles detachment from supports involved in traditional methodologies, we demonstrate a versatile electrodeposition method for growing anisotropic microstructures directly onto a threedimensional (3D) carbon felt electrode, using platinum nanoparticles as elementary building blocks. The as-synthesized materials were extensively characterized by integrating methods of physical (TGA, XRD, SEM, ICP, XPS) and electroanalytical (voltammetry, EIS) chemistry to examine the intricate relationship of material-to-performance and select the best-performing electrocatalyst to be applied in the model reaction of ORR for its practical integration into a microbial fuel cell (MFC). A tightly optimized procedure enables decorating an electrochemically activated carbon felt electrode by $40-60 \mathrm{~nm}$ ultrathin 3D-interconnected platinum nanoarrays leading to a hierarchical framework of ca. $500 \mathrm{~nm}$. Half-cell reactions reveal that the highly rough metallic surface exhibits improved activity and stability towards ORR $\left(E_{\text {onset }} \sim 1.1 \mathrm{~V}\right.$ vs. RHE, $p\left(\mathrm{HO}_{2}^{-}\right)<0.1 \%$ ) and hydrogen evolution reaction (HER, $-10 \mathrm{~mA}$ $\mathrm{cm}^{-2}$ for only $75 \mathrm{mV}$ overpotential). Owing to its unique features, the developed material showed distinguished performance as an air-breathing cathode in a garden compost MCF exhibiting better current and faster power generation than its equivalent classical double chamber. The enhanced performance of the material obtained herein is explained by the absence of any organic surfactant on the surface of the nanoarrays, the good metal-support interaction, the particular morphology of the nanoarrays, and the reduced aggregation/detachment of particles. It promises a radical improvement in current surface reactions and paves a new way towards electrodes with regulated surface roughness allowing for their successful application in heterogeneous catalysis. 


\section{INTRODUCTION}

Electrochemical energy technologies such as fuel cells (FCs) in which chemical energy is converted to electricity enables accessing clean, affordable and reliable energy to satisfy the world's increasing needs. They represent promising sustainable solutions to the looming energy crisis at the small or large scale. ${ }^{1}$ Owing to their fascinating features (high energy density, low operating temperature, green emissions), FC-based on proton exchange membrane (PEMFCs), ${ }^{2,3}$ low-temperature direct alcohol (DAFCs), ${ }^{4,5}$ microorganisms $(\mathrm{MFCs})^{6-8}$ and enzymes (EFCs) 9,10 are highly desirable for automotive/portable electricity generation, pollutant removal and implantable devices. Their performances, however, mainly rely on the activity and durability of the electrocatalysts toward the oxygen reduction reaction (ORR) and the fuel oxidation reaction (methanol, hydrogen, glucose...) at the electrodes. ${ }^{11,12}$ Only biocatalysts (enzymes) are able to drive ORR with the lowest activation overpotentials, but their high production cost, and reduced thermal and chemical stabilities makes them unsuitable for PEMFC, DAFC and MFC uses. ${ }^{6,13-17}$

MFC, considered as a green type of FC, is an electrochemical device that involves bacteria as a bio-engine converting all kinds of organic waste and inorganic matter to electricity through the aid of electroactive bacteria acting as bioanode. ${ }^{18-21}$ Wastewater being a rich source of organic matter, MFCs provide the double benefit of producing electricity and removing pollutants. ${ }^{19,20,22,23}$ Various electroactive microbial sources for FCs such as anaerobic sludge, marine sediment, domestic wastewater, garden compost and manure have been reported. ${ }^{19,24,25}$ However, some factors should be considered such as abundance, ease of handling, and relative toxicity (non-pathogenic microbial). Owing to its rich microbial content, abundant source of inoculums and suitable environment, garden compost seems to fit with most requirements to empower MFCs. ${ }^{24,26}$ Previous works with garden compost were mostly operated in a classical 
double chamber MFC. ${ }^{24,27}$ However, this classical system is facing many limitations when come up in large scale application and as alternative, single chamber MFC with air-breathing cathode system using garden compost is initiated. ${ }^{28}$ Nonetheless, its power production is still very low. Therefore, the search for efficient cathode and bioanode catalysts has become a prerequisite for using MFCs.

To improve ORR efficiency with low platinum group metals (PGMs) content, the direct growth of catalysts onto supports such as carbon papers (known as 'gas diffusion layer, GDL') allowing for a better control and higher catalyst utilization has been introduced. ${ }^{29-33}$ This approach enables a better electrode durability by preventing the catalyst agglomeration through anchoring the nanoparticles (NPs) to the carbon surface and minimizing carbon corrosion. ${ }^{33} \mathrm{Up}$ to now, the overwhelming majority within the state-of-the-art ORR electrocatalysts are in a form of fine NPs dispersed either on conducting carbon powders or in a liquid in presence of stabilizing surfactants before coating onto electrodes for tests. ${ }^{12,34,35}$ Subject to long-term stability and/or repetitive cycles during the FC operation, the electrochemical active surface area (ECSA) of the catalyst decreases because of the NPs migration and sintering, metal dissolution and redeposition at lower potentials either in the membrane or on bigger NPs (Ostwald ripening), and carbon substrate corrosion that causes NPs detachment. ${ }^{33-36}$ The emerging methods for the improvement in each of the above shortcomings of electrocatalysis include methods of electrodeposition, sputter deposition and chemical reduction. ${ }^{35-37}$ It has been shown that the direct growth of $\mathrm{Pt}, \mathrm{Pd}, \mathrm{Au}$ NPs directly onto large surface, up to $50 \mathrm{~cm}^{2}$ geometric ${ }^{31}$, threedimensional (3D) structures such as carbon papers or carbon fibers enables increasing significantly the catalytic properties. ${ }^{29-31}$ The entire catalyst layer is in such intimate contact with the electrode that the need for binders such as Nafion for the inks preparation (contributes to the 
proton transport within the electrode) is partially resolved. Yet, carbon and graphite materials have been used in most studies on oxygen microbial cathodes such as graphite plates, glassy carbons, carbon papers, carbon felts, graphite granules and graphite fiber brushes. ${ }^{6}$ Herein, we initiate self-assembly of Pt NPs on a carbon felt (CF), pre-activated, as a remarkable method to synthesize electrocatalysts with high ORR activity and durability at various $\mathrm{pH}$ range. The developed convenient electrodeposition approach without introducing any template or organic surfactant enables simplifying the various preparation and post-synthesis steps. We firstly interrogated the functional surface state of $\mathrm{CF}$ by initiating a convenient activation process. In subsequent ultimate attempts, we studied the effect of synthesis parameters, e.g. electrochemical technique, reaction duration, and concentration of metal precursor. The present direct fabrication method led to a high Pt utilization, a robust electrode impeding NPs migration, and a better electrical NPs-support contact. Finally, a simple but efficient air-breathing cathode system was developed and applied in garden compost MFC. Different with precedent work, in this research, the electroactive biofilm was self-developed without electrical driving force that constitutes an important technological jump since eliminating the energy needed for the bioanode development. The synthesis process reported herein can be readily extended to other kinds of paper-based electrodes for widespread use in catalysis and surface processes.

\section{EXPERIMENTAL SECTION}

Chemicals and Materials. Carbon felt (CF, $6.35 \mathrm{~mm}$ thick, 99\%) was purchased from Alfa Aesar. Sulfuric acid $\left(\mathrm{H}_{2} \mathrm{SO}_{4}, 97 \%\right)$, ethanol (VWR, 96\%), hexahydrate hexachloroplatinic(IV) acid $\left(\mathrm{H}_{2} \mathrm{PtCl}_{6} \cdot 6 \mathrm{H}_{2} \mathrm{O}, 99 \%\right)$, sodium phosphate monobasic monohydrate $\left(\mathrm{NaH}_{2} \mathrm{PO}_{4} \cdot \mathrm{H}_{2} \mathrm{O}, 99 \%\right)$, 
potassium chloride $(\mathrm{KCl}, 99 \%)$ and potassium nitrate $\left(\mathrm{KNO}_{3}, 99 \%\right)$ were obtained from SigmaAldrich. Sodium phosphate dibasic dihydrate $\left(\mathrm{Na}_{2} \mathrm{HPO}_{4} \cdot 2 \mathrm{H}_{2} \mathrm{O}, 98 \%\right.$, Fluka Analytical), and potassium ferricyanide $\left(\mathrm{K}_{3}\left[\mathrm{Fe}(\mathrm{CN})_{6}\right], 99 \%\right.$, Merck), potassium hydroxide $(\mathrm{KOH}, 85 \%$, Prolabo), sodium acetate (99\%, Carlo Erba Reagents), and garden compost (Neuhaus) were used asreceived. All used oxygen $\left(\mathrm{O}_{2}\right)$ and nitrogen $\left(\mathrm{N}_{2}\right)$ gas were ultrapure (Air Liquide, France). All named ultrapure water is obtained from a Milli-Q Millipore source $\left(18.2 \mathrm{M} \Omega \mathrm{cm}\right.$ at $\left.20^{\circ} \mathrm{C}\right)$.

Activation of 3D CF Electrodes. Typical experiments were performed using a rectangular parallelepiped CF (bulk density of $76 \mathrm{mg} \mathrm{cm}^{-3}$, i.e. $22 \mathrm{mg} \mathrm{cm}^{-2}$ ) constitutes of $1 \mathrm{~cm} \mathrm{high,} 1 \mathrm{~cm}$ wide and $0.635 \mathrm{~cm}$ thickness (i.e. a geometric area of $3.9 \mathrm{~cm}^{2}$ available for the entire 5 exposed rectangular surfaces). In an L-shape configuration, the sample is dangled into the solution while the upper side of the electrode is protected by the Teflon. Given its 3D morphology, it is obvious that the real geometric surface area of CF is higher than $3.9 \mathrm{~cm}^{2}$. All the reported data herein are normalized using this area. For the scale-up, larger dimensions were considered ( $\geq 3 \mathrm{~cm})$. To remove any impurity resulting from the industrial manufacturing process, as-received CFs were ultrasonically cleaned in ethanol for $2 \mathrm{~h}$, washed with water thoroughly and let to dry in an oven at $70{ }^{\circ} \mathrm{C}$ overnight before further used and referred as raw carbon felt (RCF). RCF samples were electrochemically pretreated in $1 \mathrm{M} \mathrm{H}_{2} \mathrm{SO}_{4}$ by cyclic voltammetry (CV) from 0 to $1.5 \mathrm{~V}$ vs. $\mathrm{Ag} / \mathrm{AgCl}$ for 30 cycles at $20 \mathrm{mV} \mathrm{s}^{-1}$. Then, the samples were thoroughly rinsed with water until neutral $\mathrm{pH}$, finally dried in oven at $70{ }^{\circ} \mathrm{C}$ (referred as ACF). A SP-50 potentiostat (Biologic Science Instruments) was used during the entire electrochemical measurements.

Growth of Pt Nanoarrays on 3D ACF Electrodes by the Method of CV. After preliminary tests, the Pt electrodeposition on ACF was carried out by the method of $\mathrm{CV}$ at $20 \mathrm{mV} \cdot \mathrm{s}^{-1}$ from 0 
to $-1 \mathrm{~V}$ vs. $\mathrm{Ag} / \mathrm{AgCl}$ for 30 cycles in $5 \mathrm{mM} \mathrm{H}_{2} \mathrm{PtCl}_{6}$ ( $\mathrm{pH}$ adjusted to 9) under $\mathrm{N}_{2}$ atmosphere. Preliminary tests under ambient air resulted in a lower electrocatalytic performance, likely due to a concomitant ORR. Syntheses were performed in a three-electrode configuration where ACF, saturated silver-silver chloride $(\mathrm{Ag} / \mathrm{AgCl})$ and platinum mesh act as working, reference and counter electrodes, respectively. After electrodeposition, the sample is rinsed and dried at $70{ }^{\circ} \mathrm{C}$. The as-fabricated sample is labeled as ACF@Pt_CV, meaning ACF decorated by Pt NPs.

\section{Growth of Pt Nanoarrays on 3D ACF Electrode by the Method of Chronoamperometry}

(CA). A method of constant electrode potential also referred as chronoamperometry was used for the in situ generation of Pt NPs, directly onto ACF. After preliminary tests, the Pt electrodeposition was fulfilled at $E_{\text {appl }}=-0.60 \mathrm{~V}$ vs. $\mathrm{Ag} / \mathrm{AgCl}$ (i.e. $0.14 \mathrm{~V}$ vs. reversible hydrogen electrode (RHE) at $\mathrm{pH}$ 9) by varying parameters such as the reaction time and the amount of the precursor, i.e. $\left[\mathrm{PtCl}_{6}^{2-}\right]$. It is worth noting that the applied potential is significant lower than the standard redox potential of $\mathrm{PtCl}_{6}^{2-} / \mathrm{Pt}\left(E^{\circ}=0.7 \mathrm{~V}\right.$ vs. $\mathrm{SHE}=0.5 \mathrm{~V}$ vs. $\left.\mathrm{Ag} / \mathrm{AgCl}\right)$, thus proving enough thermodynamic driving force (Eq. 1) for deposition and growth $\left(\mathrm{Pt}^{+\mathrm{IV}}\right.$ reduction to $\left.\mathrm{Pt}^{0}\right)$.

$$
\mathrm{H}_{2} \mathrm{PtCl}_{6(\mathrm{~s})} \stackrel{\text { dissolutin/dissocition }}{\longrightarrow} 2 \mathrm{H}^{+}(\mathrm{aq})+\mathrm{PtCl}_{6(\text { (aq })}^{2-} \stackrel{\text { electrodepstion }}{\longrightarrow} \mathrm{Pt} \mathrm{NPs}
$$

Syntheses were performed as described above by changing either the reaction duration or $\left[\mathrm{PtCl}_{6}^{2-}\right]$. For time-dependent materials, durations of $0.5,1,2$ and $5 \mathrm{~h}$ were probed at $\left[\mathrm{PtCl}_{6}^{2-}\right]=$

5 mM. Resulting samples are labeled as ACF@Pt_CA-T0.5, ACF@Pt_CA-T1, ACF@Pt_CAT2, and ACF@Pt_CA-T5, respectively. Then the best compromise of 1 h was used for different $\left[\mathrm{PtCl}_{6}^{2-}\right]$ concentrations of $1,2,3,5$ and $7 \mathrm{mM}$. The samples are named as ACF@Pt_CA-C1, ACF@Pt_CA-C2,ACF@Pt_CA-C3,ACF@Pt_CA-C5, and ACF@Pt_CA-C7, respectively. 
Material Characterizations. The thermogravimetric analysis (TGA) was used to evaluate the metal loading, carried out on a TA Instrument SDT 2960 apparatus equipped with TA Universal Analysis software. ${ }^{38}$ Typically, a representative sample of $15-20 \mathrm{mg}$ was put in a platinum crucible, thermally heated under air flow of $60 \mathrm{~mL} \min ^{-1}$ at $10{ }^{\circ} \mathrm{C} \min ^{-1}$ to $600{ }^{\circ} \mathrm{C}$ followed by an isotherm of $600{ }^{\circ} \mathrm{C}$ for $60 \mathrm{~min}$ and finally at $10{ }^{\circ} \mathrm{C} \mathrm{min}{ }^{-1}$ to $800^{\circ} \mathrm{C}$. X-ray diffraction (XRD) was used to determine the crystallographic structure and the crystallite size of the as-synthesized materials. ${ }^{38}$ The raw XRD data were recorded using PANalytical Xpert-PRO diffractometer (X'celerator detector employing nickel filter) in Bragg-Brentano $(\theta-\theta)$ configuration and powered at $40 \mathrm{kV}$ and $20 \mathrm{~mA}\left(\mathrm{Cu}_{\mathrm{k} \alpha 1}=1.54060 \AA\right.$ and $\left.\mathrm{Cu}_{\mathrm{k} \alpha 2}=1.54443 \AA\right)$. Data were collected from 10 to $80^{\circ}$ in $2 \theta$ (a step of $0.017^{\circ}$ ) at $55.245 \mathrm{~s} / \mathrm{step}$. Finally, information on interest was extracted from the patterns by using the common pseudo-Voigt function on HighScorePlus software; however, XRD patterns shown herein are not fitted. ${ }^{38}$ Textural and morphological analyses of the materials were performed using scanning electron microscopy (SEM) on a Hitachi S-4800 microscope. ${ }^{38}$ The surface state characterization was performed using X-ray photoelectron spectroscopy (XPS) on a ESCALAB 250 spectrometer (Thermo Electron, monochromatic radiation source Al-K $\left.\alpha=1486.6 \mathrm{eV}^{39,40}\right)$. As indicated elsewhere, ${ }^{39,40}$ survey spectra were collected with a step of $1 \mathrm{eV}$ (transition energy: $150 \mathrm{eV}$ ) and high-resolution spectra were recorded at a step of $0.1 \mathrm{eV}$ (transition energy: $20 \mathrm{eV}$ ). The measurement of binding energy (BE) was corrected based on the energy of $\mathrm{C} 1 \mathrm{~s}$ at $284.4 \mathrm{eV}$ and quantifications were carried out from the corresponding XPS peak area after correction with suitable sensitivity factor. ${ }^{39,40}$ Quantitative analysis by the inductively coupled plasma mass spectrometry was performed on an ICP-MS iCAP Q (Thermo Scientific) at the AETE-ISO platform (OSU-OREME/Université de Montpellier). Fourier transform infrared spectroscopy (FTIRS) analysis was carried out on a 
Nicolet Nexus FTIR spectrometer (Thermo Electron Corporation). Contact angle measurements were performed by the water droplet method (ultrapure water aliquot of $6 \mu \mathrm{L}$ is dropped on the electrode), using a Low-bond axi-symmetric drop shape analysis (LBA-ADSA) technique.

Electrochemical Measurements. The entire half-cell electrochemical tests were fulfilled in a conventional three-electrode cell using the above potentiostat. The working electrode is fabricated to yield a rectangular parallelepiped of $1 \mathrm{~cm}$ high, $1 \mathrm{~cm}$ wide and $0.635 \mathrm{~cm}$ thickness (see above for the disposition in the cell). The reference and counter electrodes were a saturated $\mathrm{Ag} / \mathrm{AgCl}$ and large Pt mesh, respectively. However, the majority of the potentials were scaled herein versus RHE according to Eq. 2 where $E_{\mathrm{Ag} / \mathrm{AgCl}}^{\circ}=0.20 \mathrm{~V}$ vs. standard hydrogen electrode (SHE) at $20-25{ }^{\circ} \mathrm{C}$. Depending on the intended application, the electrolytic solution consists of either $0.1 \mathrm{M} \mathrm{KOH} \mathrm{(pH} \mathrm{13)} \mathrm{or} 50 \mathrm{mM}$ of phosphate-buffered saline (PBS: $\mathrm{pH}$ 7, $50 \mathrm{mM} \mathrm{KCl}$ ). For $\mathrm{CV}$, the solution was completely deoxygenated with $\mathrm{N}_{2}$ while $\mathrm{ORR}$ polarization curves are obtained with saturated $\mathrm{O}_{2}{ }^{40}$ The stability tests were performed under $\mathrm{O}_{2}$ atmosphere using the method of CA at different electrode potentials. Electrochemical impedance spectrometry (EIS) was performed by scanning frequencies from $50 \mathrm{KHz}$ to $25 \mathrm{mHz}(10 \mathrm{mV}$ amplitude) at different electrode potentials using a SP-150 potentiostat. Hydrogen evolution reaction (HER) was evaluated by LSV at $5 \mathrm{mV} \mathrm{s}^{-1}$ in a deoxygenated $0.1 \mathrm{M} \mathrm{KOH}$ solution and stability was performed by CA at $-0.12 \mathrm{~V}$ vs. RHE. All the measurements were done at room temperature.

$$
E(\mathrm{~V} \text { vs. } \mathrm{RHE})=E(\mathrm{~V} \text { vs. } \mathrm{Ag} / \mathrm{AgCl})+0.06 \mathrm{pH}+E_{\mathrm{Ag} / \mathrm{AgCl}}^{\circ}(\mathrm{V} \text { vs. SHE }) \quad \text { at } 25^{\circ} \mathrm{C}
$$

Analytical Measurements for Hydrogen Peroxide $\left(\mathrm{H}_{2} \mathrm{O}_{2}\right)$ Quantification. CA experiments were performed as described above for ORR (the counter electrode is a glassy carbon, $20 \mathrm{~mL}, 1$ h) on $\operatorname{RCF}\left(E_{\text {appl }}=0.5 \mathrm{~V}\right.$ vs. RHE), $\mathrm{ACF}\left(E_{\text {appl }}=0.5\right.$ and $0.6 \mathrm{~V}$ vs. RHE $)$, and $\mathrm{ACF} @ \operatorname{Pt}\left(E_{\text {appl }}=\right.$ 
0.5, 0.6 and $0.8 \mathrm{~V}$ vs. RHE). Since $\mathrm{pKa}\left(\mathrm{H}_{2} \mathrm{O}_{2} / \mathrm{HO}_{2}{ }^{-}\right)=11.75$, any produced $\mathrm{H}_{2} \mathrm{O}_{2}$ from the incomplete ORR is the form of $\mathrm{HO}_{2}{ }^{-}$. Samples were then acidified toward $\mathrm{pH} 3.5$, and the resulting $\mathrm{H}_{2} \mathrm{O}_{2}$ was quantified by spectrophotometry using potassium titanium(IV) oxalate as a colored indicator $^{41-43}$ via a calibration curve obtained from standard solutions. The absorbance of the yellow pertitanic acid complex between $\mathrm{H}_{2} \mathrm{O}_{2}$ and potassium titanium oxalate in acidic solution was measured by a Jenway 6300 spectrophotometer (Barioworld Scientific Ltd, Dunmow, UK) at $\lambda=400 \mathrm{~nm}$ through a $1 \mathrm{~cm}$ polystyrene cuvette. ${ }^{43}$

Application towards a Microbial Fuel Cell. ACF@Pt with dimensions of $3 \mathrm{~cm}$ high, $3 \mathrm{~cm}$ wide and $0.635 \mathrm{~cm}$ thickness (i.e. a geometric area of $23.7 \mathrm{~cm}^{2}$ available for the entire 5 exposed rectangular surfaces) as an air-breathing cathode was prepared using optimal conditions (1 h, 5 $\mathrm{mM})$. RCF $(10 \times 1 \times 0.635 \mathrm{~cm})$ was used as supporting electrode to grow microbial anode. The inoculums source was the garden compost leachate obtained by lixiviation as explained in previous work. ${ }^{27}$ Garden compost and $60 \mathrm{mM}$ potassium chloride solution (equivalent volume ratio of 1:1) were mixed and stirred for $24 \mathrm{~h}$. The garden compost leachate was separate by rough filtration using sieve. Sodium acetate was added to the garden compost leachate hence giving a final concentration of $20 \mathrm{mM}$. Two configurations of MFC applications have been probed, as depicted in Figure 1. The first system was oriented as classical double chamber microbial fuel cell (cDCMFC) and the second one as air-breathing microbial fuel cell (ACMFC). Both systems involve Nafion ${ }^{\circledR} 115$ as proton exchange membrane (PEM) that was soaked in water overnight. The anodic compartment of both systems was filled by the mixture of garden compost leachate and acetate, and closed to maintain anaerobic environment. In the cDCMFC system, the cathodic part was filled with $20 \mathrm{mM}$ potassium ferricyanide solution and stainless steel $(4 \times 1 \times 0.1 \mathrm{~cm})$ was dipped inside as cathode. For the ACMFC system, the air-breathing cathode was prepared 
by adhering Nafion ${ }^{\circledR} 115$ PEM to ACF@Pt electrode, $3.14 \mathrm{~cm}^{2}$ exposed surface area. The Nafion ${ }^{\circledR} 115$ PEM side faced anodic solution while ACF@Pt was exposed to free air. MFC were firstly characterized by recording: (i) the open circuit voltage (OCV) until a steady-state and (ii) polarization curves by the constant resistance discharge technique where variable external resistance are applied to the cell, ranging from $0.1 \mathrm{M} \Omega$ to $10 \Omega{ }^{30,44}$ The current and power were derived from the applied resistance and the measured cell voltage (using a high-impedance multimeter $){ }^{30}$ The MFC metrics of current density $\left(j, \mathrm{~mA} \mathrm{~m}^{-2}\right)$ and power density $\left(P, \mathrm{~mW} \mathrm{~m}^{-2}\right)$ are given as a function of the geometric surface area of the current-limiting electrode that is the cathode. ${ }^{44}$ For the durability tests, a resistance-load $R(=1 \mathrm{k} \Omega)$ was connected to the MFC and the generated voltage $E$ was monitored by a high-impedance multimeter $\left(j=E \times R^{-1}\right)$.

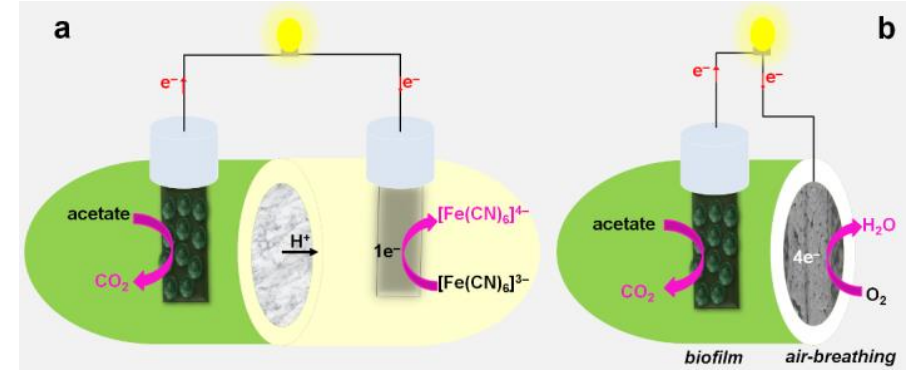

Figure 1. Two equal anodic-chamber MFC reactor: (a) Classical double chamber (cDCMFC), and (b) The design air-breathing cathode (ACMFC) employing ACF@Pt electrode material.

\section{RESULTS AND DISCUSSION}

Setup of Substrate Activation and the Method for Pt Particles Growth. The modification of carbon paper/felt substrates by metallic (nano)particles for electrocatalytic purposes rely on two 
distinguished approaches. ${ }^{31}$ In a more traditional method, pre-synthesized materials (solution or powder) are re-dispersed to form a homogeneous catalytic ink before the incorporation on the support while simplified method for the direct growth of metallic particles involved the reduction of metallic ions directly onto the support using a chemical reducing agent or electrical driving force. Guided by the simplicity of the second methodology, we aimed in a first experimental attempt to load Pt NPs (in situ growth process, see next sections) on the as-received CF or the cleaned material (RCF). All attempts to deposit significant amount failed, likely because of the possible high repulsing force between RCF surface and Pt NPs being deposited. Indeed, it was previous argued that carbon felt electrodes (3 and $10 \mathrm{~mm}$ thickness samples) are highly hydrophobic in nature. ${ }^{43,45,46} \mathrm{We}$ then used the water droplet method to question the wettability of our received CF (6.35 mm thickness) and cleaned RCF electrodes wherein the further produced ACF and ACF@Pt electrodes are used for a better comparison. Photographs within Figure 1a show the very slow penetration of a water droplet into the RCF electrode. Extended pictures within Figure S1 state that upon the contact with either ACF or ACF@Pt electrode surface, the droplet enters instantaneously into the 3D-electrode matrix. We therefore initiated an activation step to lower the hydrophobic character of RCF samples by treating them electrochemically in $1 \mathrm{M} \mathrm{H}_{2} \mathrm{SO}_{4}$ aqueous solution by $\mathrm{CV}$ from 0 to $1.5 \mathrm{~V}$ vs. $\mathrm{Ag} / \mathrm{AgCl}$ for 30 cycles at a scan rate of $20 \mathrm{mV} \mathrm{s}^{-1}$. Figure $2 \mathrm{~b}$ depicts CVs of RCF (black) and resulting activated carbon fiber (ACF, red curve) electrodes in $0.1 \mathrm{M} \mathrm{KOH}$ electrolyte. It can be qualitatively observed that ACF electrode produces much higher current density than RCF electrode does. More importantly, when ORR was used as a model reaction to examine their electrocatalytic abilities, the as-activated ACF sample outperformed RCF electrode (Figure 2c). Indeed, the activation process leads to oxygenated functions on ACF surface (see XPS results), which makes 
it more hydrophilic. We then sought to find the best configuration to electrochemically deposit Pt NPs on ACF by examining methods of CV (ACF@Pt_CV) and CA (ACF@Pt_CA), as described above. The recorded blank CVs and ORR polarization curves are displayed within Figures $2 \mathrm{~b}$ and 2c. Typically, the hydrogen desorption from Pt sites occurs during the positive potentialgoing scan between 0.05 and $0.45 \mathrm{~V}$ vs. RHE, followed by the double layer charging current up to $0.75 \mathrm{~V}$ vs. RHE and finally the Pt surface oxidation at higher potentials. ${ }^{47}$ In the reverse scan, the Pt oxide reduction corresponding to the cathodic peak takes place at $0.80 \mathrm{~V}$ vs. RHE. ${ }^{47}$ Then, the Pt free surface is covered by adsorbed hydrogen in the lower potential region (from 0.45 to $0.05 \mathrm{~V}$ vs. RHE). ${ }^{47}$ The magnitude of the hydrogen region current density stipulates that the CA method leads to a higher ECSA, which is supported by ORR data where ACF@Pt_CA is more efficient. This gap may certainly come from the deposited amount of Pt. Thus, CA method was used. To investigate the possible interference of the dissolved oxygen $\left(\mathrm{O}_{2(\mathrm{~d})}\right)$ from the ambient air and that produced at the counter electrode during the electrodeposition, we run control tests by pulling out $\mathrm{O}_{2(\mathrm{~d})}$. The corresponding $\mathrm{CVs}$ are reported within Figure $\mathrm{S} 2 \mathrm{a}$ and highlight enhanced electrochemical properties for the sample obtained under nitrogen atmosphere, even with a reduced electrodeposition time. Interestingly, its ORR polarization curve presented in Figure 1b (sample ACF@Pt_CA-T1, i.e. ACF decorated by Pt NPs by the method of CA for $1 \mathrm{~h}$ as reaction time)) underpins the conclusion that an inert atmosphere enables the fabrication of high-performance materials by cancelling $\mathrm{O}_{2(\mathrm{~d})}$ interferences such as concomitant $\mathrm{ORR}$, and the localized oxidative capability of $\mathrm{Cl}^{-} / \mathrm{O}_{2}$ etchant $\mathrm{t}^{31,48,49}$ that can oxidize $\mathrm{Pt}^{0}$ back to $\mathrm{PtCl}_{6}^{2-}$. Having successfully modified the surface of CF and subsequently deposited Pt NPs, we next design experiments to interrogate their surface ability to transfer electrons. 

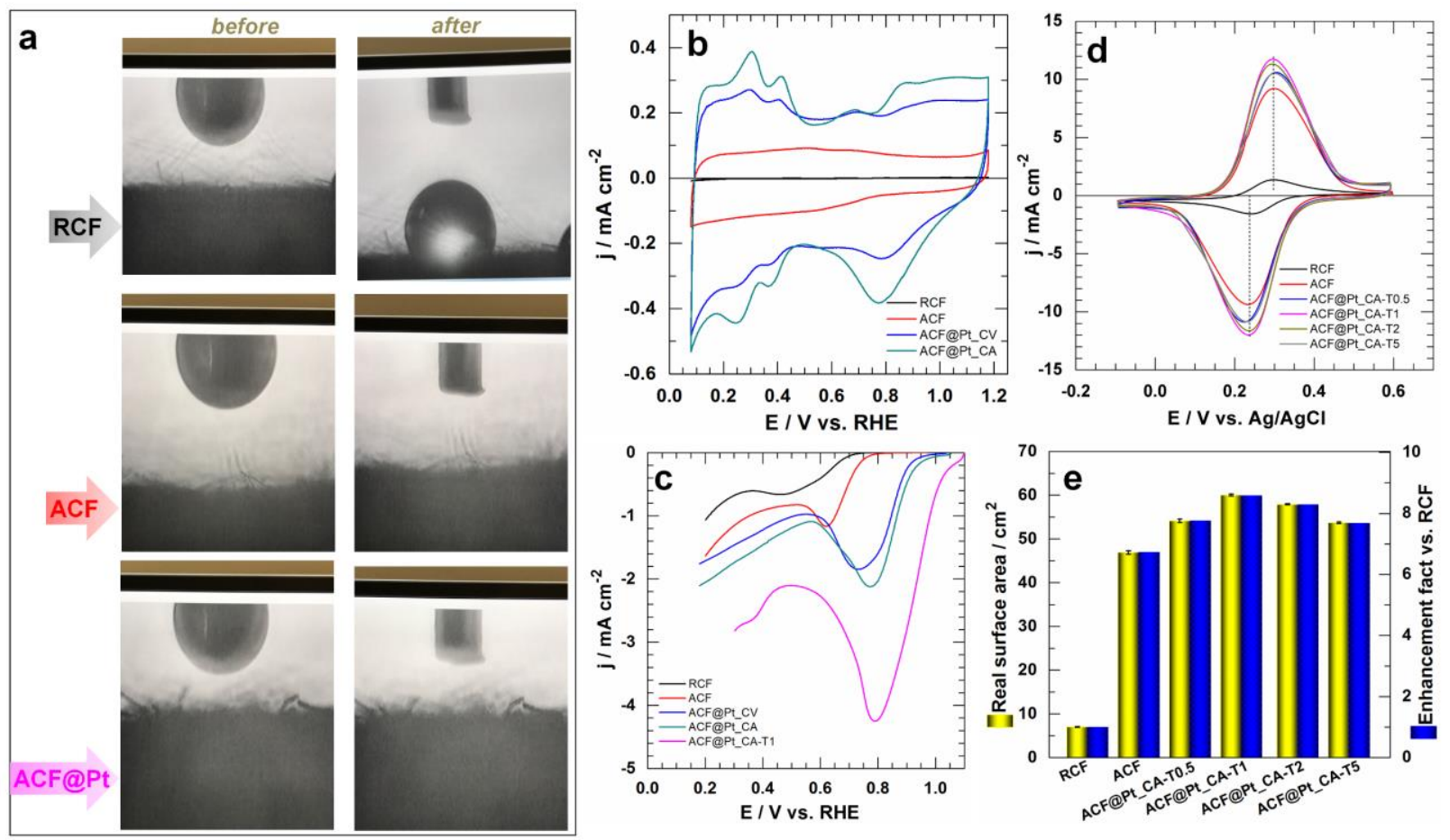

Figure 2. (a) Photographs recorded on RCF, ACF and ACF@Pt electrodes (from top to down) before and after a water droplet contact with the electrode surface (from left to right). (b) Steadystate CVs recorded in $\mathrm{N}_{2}$-saturated $0.1 \mathrm{M} \mathrm{KOH}$ aqueous solution at $5 \mathrm{mV} \mathrm{s}^{-1}$ on pristine $\mathrm{RCF}$, pretreated (ACF), and Pt decorated ACF by method of CV (ACF@Pt_CV) or CA (ACF@Pt_CA) in ambient air. (c) iR-uncorrected ORR polarization curves recorded at $5 \mathrm{mV} \mathrm{s}^{-1}$ in $\mathrm{O}_{2}$-saturated $0.1 \mathrm{M} \mathrm{KOH}$ aqueous solution on pristine RCF, bare ACF, Pt decorated ACF by method of CV (ACF@Pt_CV) or CA (ACF@Pt_CA) in ambient air, and Pt decorated ACF by method of CA (ACF@Pt_CA-T1) under $\mathrm{N}_{2}$ atmosphere. (d) Steady-state CVs (iR-free) recorded at $10 \mathrm{mV} \mathrm{s}^{-1}$ in $10 \mathrm{mM} \mathrm{K}_{3}\left[\mathrm{Fe}(\mathrm{CN})_{6}\right]+1 \mathrm{M} \mathrm{KNO}_{3}$ on pristine RCF, bare ACF and ACF@Pt_CA (by method of $\mathrm{CA}$ under $\mathrm{N}_{2}$ for reaction time of $0.5,1,2,5 \mathrm{~h}$ ) electrode materials. (e) Corresponding real active surface (left $x$-axis) based on the used electrode of $S_{\mathrm{g}}=3.9 \mathrm{~cm}^{2}$ geometric surface area and enhancement factor (right $y$-axis: $\mathrm{RCF}=$ reference): Error bars represent one standard deviation $(n=3)$. 
Different materials of ACF@Pt were obtained during the time-dependent experiments, where the reaction is quenched after 0.5, 1, 2 and $5 \mathrm{~h}$ hereafter referred to as ACF@Pt_CA-T0.5 and so on. The quasi-reversible $\mathrm{Fe}(\mathrm{CN})_{6}^{3-} / \mathrm{Fe}(\mathrm{CN})_{6}^{4-}$ redox probe (sensible to microstructure) was used to determine the real electroactive area $\left(S_{\mathrm{r}}\right)$ through the Randles-Sevcik's equation wherein the peak current density $\left(j_{\mathrm{p}}\right)$ is proportional to $\mathrm{S}_{\mathrm{r}}{ }^{50,51}$ Figure $2 \mathrm{~d}$ shows steady-state CVs (after ohmic drop correction) where the two oxidative and reductive waves are associated to the $\mathrm{Fe}(\mathrm{CN})_{6}^{3-}+1 \mathrm{e}^{-}=\mathrm{Fe}(\mathrm{CN})_{6}^{4-}$ process that is fully reversible. Indeed, the peak-to-peak difference is ca. $60 \mathrm{mV}$ and $\left|\frac{\mathrm{I}_{\mathrm{c}}}{\mathrm{I}_{\mathrm{a}}}\right| \approx 1$, corresponding to the theoretical $\Delta E_{\text {peak }}=\frac{60 \mathrm{mV}}{n}, n=1$. Furthermore, $j_{\mathrm{p}}$ is 8-fold higher for ACF compared to the pristine RCF material, thus supporting its improved electron transfer capability after treatment. The determined values of $S_{\mathrm{r}}$ are presented in Figure 1e and gathered within Table 1; thus highlighting an augmentation of the available active sites at ACF. Moreover, the modification of ACF by Pt NPs results in a slight increase of $S_{\mathrm{r}}$. In an ultimate effort to scrutinize and find out the origin of the enhanced performances of ACF over RCF, EIS experiments were implemented to evaluate both the ionic conductivity of the system and the electron transfer ability of electrodes. Complex-plane Nyquist impedance plots for RCF, ACF and ACF@Pt (CA-T1 sample) electrodes recorded at the open circuit potential (i.e. 0.35, 0.42 and 0.41 V vs RHE for RCF, ACF and ACF@Pt, respectively) are reported within Figure S2b. A slightly depressed semicircle for ACF and ACF@Pt is characteristic of a charge-transfer process (with contribution of diffusion within the 3D network of CF). The intersection between the Nyquist curve and $x$-axis at high frequencies enables extracting the ohmic resistance $\left(R_{\Omega}\right.$, making the measured overpotential of the electrode larger than the true value) also referred as cell resistance. ${ }^{52} R_{\Omega}$ is the resistance between the reference electrode and the surface of the 
working electrode in a conventional three-electrode measurement and includes contribution from the connections, the electrolyte, and electrode material resistance. $R_{\Omega}$ is about $3.2,2.3$ and $1.2 \Omega$ $\mathrm{cm}^{2}$ for RCF, ACF and ACF@Pt, respectively. Since the setup configuration was kept unchanged, these results show that the electrode-electrolyte interface itself causes an extra potential drop in the order RCF (hydrophobic character) > ACF (hydrophilic character) $>$ ACF@Pt (metallic character). The determined charge-transfer resistance $\left(R_{\mathrm{ct}}\right.$, using a geometric surface of $3.9 \mathrm{~cm}^{2}$ ) of $1.2 \Omega \mathrm{cm}^{2}$ for ACF@Pt, $3.9 \Omega \mathrm{cm}^{2}$ for ACF, and $>100 \Omega \mathrm{cm}^{2}$ for RCF greatly supports the effectiveness of a faster electron transfer ability of ACF@Pt. Indeed, the metric of $R_{\mathrm{ct}}$ (inversely proportional to the exchange current density, $j_{0}$ ) reflects the ability of electron transfer and the difficulty of an electrode reaction for driving larger current density with a minimum driving force. ${ }^{52}$ It is also correlated to the number of electrons that are transferred from the catalytic surface to the reactant(s) as well as intermediate(s) formation inside the double layer. ${ }^{53}$ For a given electrode, the big $R_{\mathrm{ct}}$ is, the lower is the kinetic rate and the lesser is the driving force. ${ }^{53}$ Thus, $R_{\mathrm{ct}}$ is highly desired to be as small as possible for faster electrochemical kinetics. The decrease of $R_{\mathrm{ct}}$ from RCF to ACF and from ACF to ACF@Pt is rationally explained by the increase of active sites density, resulting from the enhanced real electroactive area (Figure 2e) as well as a better electrical conductivity upon the deposition of Pt metal on ACF.

Table 1. Summarized results from physicochemical and electrochemical characterizations by electrodeposition (chronoamperometry: CA), ICP, TGA, XRD and CV. $S_{\mathrm{g}}$ (geometric surface area), $a_{\mathrm{Pt}}($ lattice parameter of $\mathrm{Pt}), L_{\mathrm{v}}\left(\right.$ crystallite size), $S_{\mathrm{r}}($ real active surface), ECSA. $n . d .:$ not determined. 


\begin{tabular}{|c|c|c|c|c|c|c|c|c|c|}
\hline \multirow{2}{*}{ Entry } & \multirow{2}{*}{$\begin{array}{c}S_{\mathrm{g}} \\
\left(\mathrm{cm}^{2}\right)\end{array}$} & \multirow{2}{*}{$\frac{\text { CA }}{\operatorname{Pt}(\text { wt. } \%)}$} & \multirow{2}{*}{$\frac{\mathrm{ICP}}{\operatorname{Pt}(\text { wt.\%) }}$} & \multirow{2}{*}{$\begin{array}{c}\text { TGA } \\
\text { Pt(wt.\%) }\end{array}$} & \multicolumn{2}{|c|}{ XRD } & \multirow{2}{*}{$\frac{\mathrm{CV}}{S_{\mathrm{r}}\left(\mathrm{cm}^{2}\right)}$} & \multicolumn{2}{|c|}{$\mathrm{CV}: \operatorname{Pt} \mathrm{ECSA}\left(\mathrm{cm}^{2}\right)$} \\
\hline & & & & & $a_{\mathrm{Pt}}(\AA)$ & $L_{\mathrm{v}}(\mathrm{nm})$ & & $\mathrm{KOH}$ & PBS \\
\hline $\mathrm{RCF}$ & 3.9 & - & - & 0 & - & - & $\begin{array}{r}7.0 \\
\pm 0.1 \\
\end{array}$ & - & - \\
\hline $\mathrm{ACF}$ & 3.9 & - & - & 0 & - & - & $\begin{array}{r}46.9 \\
\pm 0.4\end{array}$ & - & - \\
\hline T0.5 & 3.9 & 10.4 & n.d. & 11 & 3.95 & 11 & $\begin{array}{c}54.1 \\
\pm 0.4 \\
\end{array}$ & $\begin{array}{l}680.1 \\
\pm 6.9\end{array}$ & $\begin{array}{c}422.4 \pm \\
6.1\end{array}$ \\
\hline $\mathrm{T} 1$ & 3.9 & 12.8 & 13.4 & 13 & 3.95 & 9 & $\begin{array}{r}60.0 \\
\pm 0.2\end{array}$ & $\begin{array}{l}825.1 \\
\pm 8.7\end{array}$ & $\begin{array}{c}454.8 \\
\pm 11.3\end{array}$ \\
\hline $\mathrm{T} 2$ & 3.9 & 37.2 & n.d. & 20 & 3.96 & 10 & $\begin{array}{r}57.9 \\
\pm 0.1 \\
\end{array}$ & $\begin{array}{l}716.9 \\
\pm 7.6 \\
\end{array}$ & $\begin{array}{l}356.9 \\
\pm 2.6\end{array}$ \\
\hline $\mathrm{T} 5$ & 3.9 & 117.4 & \multicolumn{4}{|c|}{ n.d. } & $\begin{array}{r}53.7 \\
\pm 0.2\end{array}$ & $\begin{array}{l}537.0 \\
\pm 3.1\end{array}$ & $\begin{array}{l}181.8 \\
\pm 8.4\end{array}$ \\
\hline
\end{tabular}

Optimization for Metal Particles Growth on the Surface of ACF: Electrochemical, Physical, and Morphological Characterization.

Time-dependent Pt particles growth on ACF. Suitability of materials for the applications mentioned above requires a precise optimization of the synthesis procedure. To this end, the electrodeposition was performed at different reaction times and Figures $3 \mathrm{a}$ and $3 \mathrm{~b}$ show CVs for blanks and LSV profiles for ORR in $\mathrm{KOH}$ solution $(\mathrm{pH} 13)$ while those in PBS $(\mathrm{pH} 7)$ are summarized in Figures $3 \mathrm{c}$ and $3 \mathrm{~d}$. The entire samples exhibit the same behavior of platinum and the reduced current density in PBS results from the low $\mathrm{pH}$. ECSAs were determined and gathered within Table 1 where the sample obtained after $1 \mathrm{~h}$ of reaction time has the highest value (from 1.2 to 1.5 times higher in $\mathrm{KOH}$ and 1.1 to 2.5 times greater in PBS). The increase of ECSA from 0.5 to $1 \mathrm{~h}$ is explained by the deposition of higher amount of Pt. However, longer reaction time may result into too much deposition of $\mathrm{Pt}$ and subsequently their growth into bigger NPs leading to lower utilization efficiency. ${ }^{54}$ Or other possibility, the accentuated localized oxidative capability of $\mathrm{Cl}^{-} / \mathrm{O}_{2}$ diminishes the number of active sites by turning out the 
rough metallic surface into smooth one. ${ }^{31,48,49}$ The high ECSA of ACF@Pt_CA-T1 is substantiated by ORR tests at $\mathrm{pH}=13$ and 7 . The drastic decrease of performance of the sample after $5 \mathrm{~h}$ can be rationally supported by the above explanation. After the normalization with $\mathrm{Pt}$ content (TGA), the specific electrochemical active surface area (SECSA) is 9,9 and $5 \mathrm{~m}^{2} \mathrm{~g}^{-1}$ for $0.5,1$ and $2 \mathrm{~h}$ samples, respectively. The trend is in agreement with LSV results. These values are lower than the conventional Pt/Vulcan samples coated onto glassy carbon or carbon fibers electrodes. ${ }^{38,47,55,56}$ One of the reasons is the large particle size (typical Pt/Vulcan is $\sim 3-10 \mathrm{~nm}$ ). ${ }^{57}$ It was observed that the 3D nature of a support such as carbon fibers decreases notably the SECSA (values range from 3 to $27 \mathrm{~m}^{2} \mathrm{~g}^{-1}$ depending on the Pt amount) ${ }^{38}$ compared to a glassy carbon electrode $\left(55 \mathrm{~m}^{2} \mathrm{~g}^{-1}\right)^{47}$ that is widely used in literature, but has no practical suitability. For a rational comparison, there are fewer data for a similar 3D supporting electrode material. ${ }^{33}$

Owing to its excellent ORR performance, the sample from $1 \mathrm{~h}$ is selected for deeper studies. During the course of the electrodeposition, the initial yellow chloroplatinic acid aqueous solution turns progressively into clear solution, indicated that $\mathrm{Pt}^{\mathrm{IV}} \mathrm{Cl}_{6}^{2-}$ is being reduced into $\mathrm{Pt}^{0}$. The amount of electrodeposited Pt was firstly evaluated by Faraday law of electrolysis (Eq. 3). The metal loading expressed as $\mathrm{Pt}(\mathrm{wt} . \%)=\frac{\mathrm{m}(\mathrm{Pt})}{\mathrm{m}(\mathrm{Pt})+\mathrm{m}(\mathrm{ACF})} \times 100$ is resumed in Table 1. Based on the experimental conditions, the maximum value is $\sim 20 \mathrm{wt} . \%$, which is confirmed for reaction time $\mathrm{T} \leq 1 \mathrm{~h}$. The obtained unrealistic values of 37 and $114 \mathrm{wt} . \%$ for $2 \mathrm{~h}$ and $5 \mathrm{~h}$ result from an overestimation of the charge Q since after the completed Pt disposition, other faradaic reactions takes place at the surface of the formed Pt NPs (such as hydrogen adsorption, $E_{\text {appl }}=0.14 \mathrm{~V}$ vs. RHE). TGA analysis was therefore necessary to determine the accurate value of Pt loading.

$$
\mathrm{m}=\frac{\mathrm{Q}}{\mathrm{F}} \times \frac{\mathrm{M}}{\mathrm{Z}}
$$


where $m$ is the mass of deposited Pt, $Q$ is total electric charge, $M$ is atomic molar mass of $\mathrm{Pt}, F$ is Faraday constant $\left(96485 \mathrm{C} \mathrm{mol}^{-1}\right)$ and $z=4$ is number of electron transferred per ion.
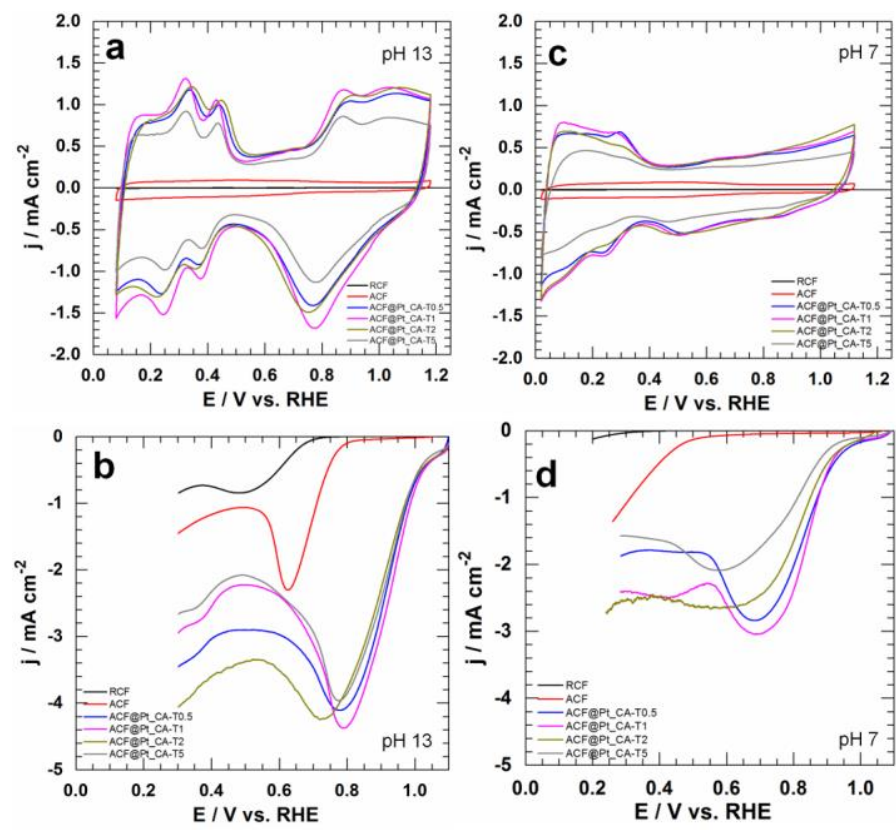

Figure 3. Electrochemical characterization and performance of pristine RCF, bare ACF, and assynthesized materials by the method of CA (ACF@Pt_CA) under $\mathrm{N}_{2}$ atmosphere for the reaction time of $0.5,1,2$, and $5 \mathrm{~h}$. Steady-state CVs recorded at $5 \mathrm{mV} \mathrm{s}^{-1}$ and iR-uncorrected ORR polarization curves recorded in: (a) $\mathrm{N}_{2}$-saturated $0.1 \mathrm{M} \mathrm{KOH}$ (pH $\sim 13$ ), (b) $\mathrm{O}_{2}$-saturated $0.1 \mathrm{M}$ $\mathrm{KOH}$ (pH 13), (c) $\mathrm{N}_{2}$-saturated $50 \mathrm{mM}$ PBS (pH 7), (d) $\mathrm{O}_{2}$-saturated $50 \mathrm{mM}$ PBS (pH 7).

Figure 4a shows TGA curves for blanks (RCF, ACF) and ACF@Pt. The carbon combustion starts around $450{ }^{\circ} \mathrm{C}$ for the entire samples, followed by an enhanced kinetics for samples containing more Pt (shift toward lower temperatures), which is not surprising since $\mathrm{Pt}$ NPs are a good catalyst for the reaction. ${ }^{47}$ An isotherm of $1 \mathrm{~h}$ at $600{ }^{\circ} \mathrm{C}$ was introduced to enables a fast carbon oxidation. However, the continuous weight loss between 600 and $700{ }^{\circ} \mathrm{C}$ 
would mean that the entire carbon was not oxidized at the isotherm and the noticed difference could be assigned to the structure of each substrate and/or the Pt-carbon interaction. Aside RCF, the process is complete above $750{ }^{\circ} \mathrm{C}$ that enables accessing the real Pt content at $800{ }^{\circ} \mathrm{C}$. The obtained values for the reaction times of 0.5 and $1 \mathrm{~h}$ confirm the calculated data (Table 1). For 2 h, 19.7 wt. $\%$ is in agreement with the theoretical maximum value of $\sim 20$ wt.\%. For a better confirmation, a representative sample for the time-dependant synthesis (ACF@Pt_CA-T1) was analyzed by ICP. The obtained metal loading of $13.4 \mathrm{wt} . \%$ substantiates the TGA outcome.

Compositional and Surface Characterization of Pt Particles Decorated Carbon Felt. Having demonstrated by $\mathrm{CV}$ and TGA the ability to use electrodeposition as an effective tool to grow NPs directly onto a carbon support, we sought to study the crystallinity, composition and morphology more carefully. XRD patterns are shown in Figure 4b. The broad diffraction peak at ca. $25^{\circ}$ corresponds to the graphite (002) plane of carbon and the one at $c a .43^{\circ}$ belongs to (111) of diamond. ${ }^{32,47}$ Those situated at $39.43^{\circ}, 45.85^{\circ}$ and $67.01^{\circ}$ correspond, respectively, to the crystallographic planes (111), (200), (220) and (311) of face-centered cubic (fcc) of Pt in the ACF@Pt material thereby confirmation its polycristallinity. The slight decrease of these positions compared to either bulk Pt (XRD reference code 98-007-641439: $39.76^{\circ}, 46.23^{\circ}$ and $67.45^{\circ}$ ) or Pt/Vulcan $\left(39.84^{\circ}, 46.30^{\circ} \text { and } 67.73^{\circ}\right)^{47}$ suggests a possible Pt-carbon electronic interaction. ${ }^{58}$ The lattice parameter $\left(a_{\mathrm{Pt}}\right)$ and crystallite size $\left(L_{\mathrm{v}}\right)$ were evaluated (Table 1$)$ using the Bragg law and Debye-Scherrer equation..$^{47,59,60}$ The determined parameter of $a_{\mathrm{Pt}} \sim 3.95 \AA$ is in agreement with the bulk Pt. ${ }^{61}$ The calculated crystallite sizes of $L_{\mathrm{v}} \sim 9-11 \mathrm{~nm}$ indicate the formation of nanoscale domains. High-resolution SEM analysis will be further used to probe this hypothesis. Furthermore, this bulk analysis by XRD indicates the formation of metallic platinum, i.e., no Pt oxide phase. However, a better sensitive surface analysis is necessary to confirm that. 
To gain deeper insights on the oxidation state and the surface chemical composition of the as-elaborated ACF and ACF@Pt materials, we used a surface technique, XPS to probe their surface together with the as-received RCF as a control material. The present technique also aims at scrutinizing the direct correlation between the physicochemical and electrochemical properties of the materials. A survey spectrum is first recorded for all materials to have an overview and a qualitative analysis (Figure S3). Then, a high-resolution spectrum is recorded for each different core-levels of interest, namely C1s (Figure 4c), O1s (Figure 4d), and Pt4f (Figure 4e). Qualitatively, the initiated activation of RCF enables introducing more oxygenate species on the surface (making the surface more hydrophilic), jointly supported by Figures $4 \mathrm{c}$ and $4 \mathrm{~d}$. The activation increases the surface oxygen content and subsequently decreases the carbon signal at the surface. Then, by decorating the fibers surface (electrodeposition), the O1s signal decreases rationally since the electrode surface becomes covered by platinum nanoarrays. These results confirm the previous electrochemical data from $\mathrm{Fe}(\mathrm{CN})_{6}^{3-} / \mathrm{Fe}(\mathrm{CN})_{6}^{4-}$ redox probe and ORR. The doublets for the same band $4 \mathrm{f}$ (Figure $4 \mathrm{e}$, results without any charge compensating with an electron beam) are related to the spin-orbit splitting ( $x \pm 1 / 2, x=3$ for the $\mathrm{f}$ band), located at BEs

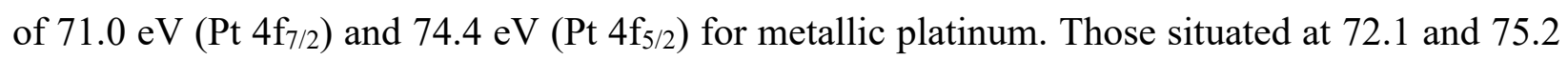
$\mathrm{eV}$ belongs to $4 \mathrm{f}_{7 / 2}$ and $4 \mathrm{f}_{5 / 2}$ levels of $\mathrm{PtO}_{x}(x \geq 2)$. The absence of oxide peaks from bulk analysis by XRD endorses completely the conclusion that the presence of the oxide is simply due to the natural oxidation of noble metal when exposed to ambient air (a thin layer prevents the surface from deep oxidation). ${ }^{39}$ Indeed, XPS probes only the surface of the materials while XRD is a technique that provides bulk information. The surface atomic composition of the samples RCF (97 at.\% C, and 3 at.\% O), ACF (87 at.\% C, and 13 at.\% O), and $\mathrm{ACF} @ \mathrm{Pt}(57$ at.\% C, and 13 at.\% $\mathrm{O}, 30$ at.\% $\mathrm{Pt}$ (i.e., 23 at.\% from metallic platinum and 7 at.\% of total contribution from 
oxidized platinum)) substantiates a surface enrichment in O-containing functional groups. FTIRS results within Figure S4 confirm a signal increase in the region between 900 and $1240 \mathrm{~cm}^{-1}$, ascribed to $\mathrm{C}-\mathrm{OH}$ (hydroxyl groups). ${ }^{46}$ The obtained results support so far the enhanced electroactive surface area, reduced charge transfer resistance and improved ORR kinetics. The high exposed Pt atoms at the surface of particles may result from the particular morphology of the particles, which will be further examined by SEM.
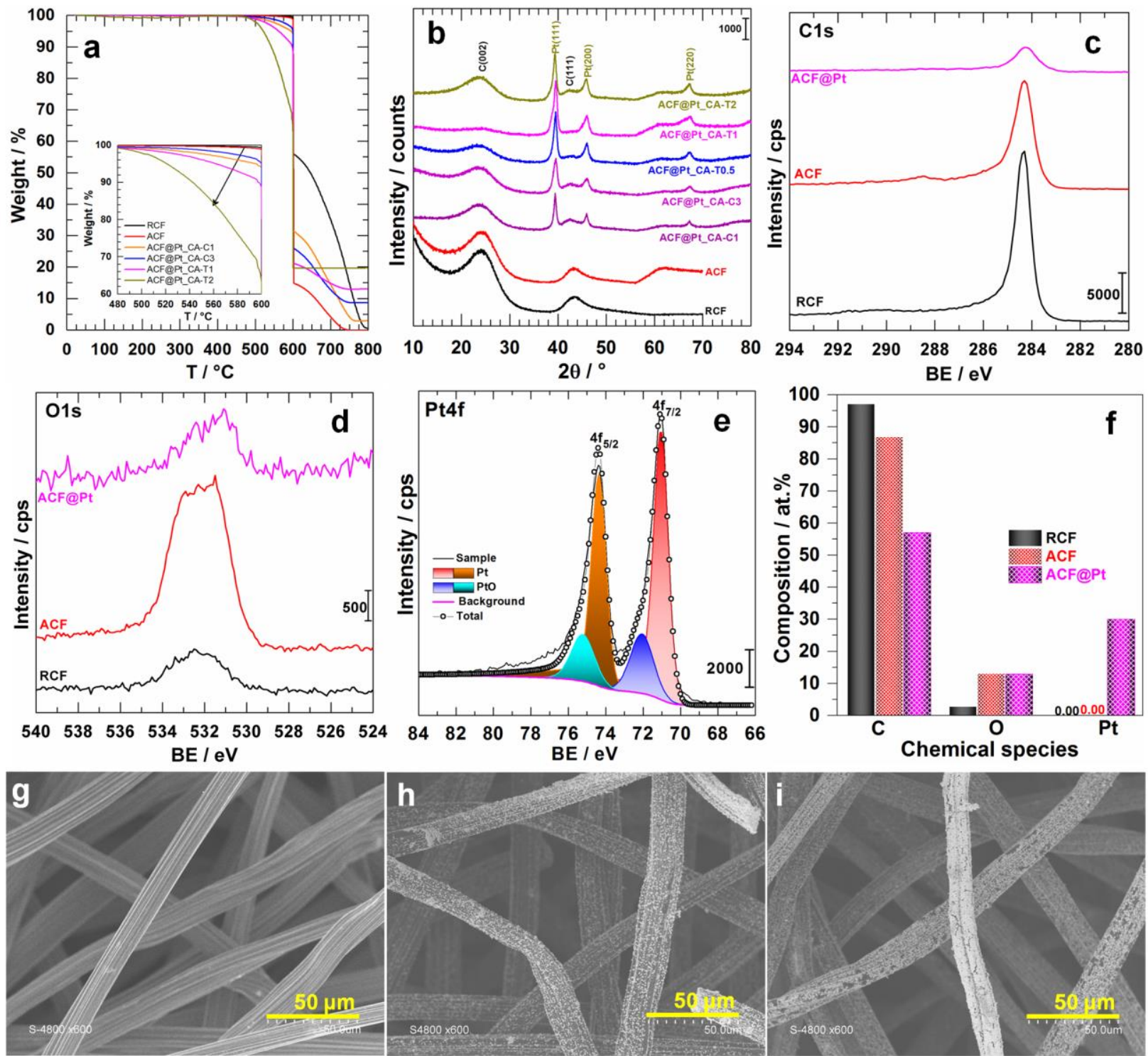
Figure 4. Physicochemical characterization of pristine RCF, bare ACF, and as-synthesized materials by the method of CA (ACF@Pt_CA) under $\mathrm{N}_{2}$ atmosphere for the reaction time of 0.5, 1, 2, and 5 h. (a) TGA curves: inset shows the weight loss between 480 and $600{ }^{\circ} \mathrm{C}$. (b) XRD patterns. High-resolution XPS spectra of C1s (c), O1s (d) and Pt4f (e) core levels for RCF, ACF and ACF@Pt_CA-T1 samples. (f) Surface atomic composition. Overview SEM micrographs of Pt particles growth on ACF for the reaction time of (g) $0 \mathrm{~h}$, (h) $1 \mathrm{~h}$, and (i) $2 \mathrm{~h}$.

Suitability of NP materials for the applications mentioned above requires control of particle localization within the 3D structure of carbon fibers. Figure 4g displays a typical SEM image of the used support showing different fibers with a size of $\sim 20 \mu \mathrm{m}$, thus composed of roughly 300 fiber layers (6.35 $\mathrm{mm}$ as electrode thickness). Representative and overview SEM micrographs of carbon surfaces containing Pt particles when the reaction was quenched at $1 \mathrm{~h}$ (Figure 4h) and $2 \mathrm{~h}$ (Figure 4i) demonstrate that the particles were successfully deposited onto the electrode' surface as well as within the 3D network (interior), suggesting that particles are preferentially being deposited onto the carbon surface. As for the case of carbon black, the reduction of metal salt takes place at the external fibers' surface. Then, the formation of the first seed layer of particles acts as an active site where further reduction occurs. The decoration of the entire fibers' surface enables (as in our previous reports for electrospinning ${ }^{30}$ ) maximizing the utilization of the high electroactive surface area of ACF compared to previous reports where either ligament of particles are formed or only the external fibers are decorated. ${ }^{29,31}$ Deeper analysis by cross-section SEM pictures (Figure S5) suggest that the distribution of Pt is not homogeneous from the surface to the interior. The electrode being thick, only the first tens of the $\sim 300$ fiber layers are covered by Pt nanoarrays. A precise knowledge of the material structure 
helps to optimize its catalytic properties..$^{47}$ To this end, the physical morphology of blanks (RCF and $\mathrm{ACF}$ ) and platinum modified carbon was examined under high-resolution SEM (HRSEM) wherein we quenched the reaction at $0.5,1$, and $2 \mathrm{~h}$ to better evaluate the influence of reaction time on the growth and subsequently the morphology of Pt particles. Figures 5a-h depicts the corresponding micrographs. After 30 minutes, Pt particles decorate the entire fibers surface (Figure 5c) where HRSEM highlights the formation of 40-60 nm ultrathin 3D particles leading to a heterogeneous surface (Figure 5d) confirming its enhanced electroactive surface area as determined previously by the $\mathrm{Fe}(\mathrm{CN})_{6}^{3-} / \mathrm{Fe}(\mathrm{CN})_{6}^{4-}$ redox probe. Then, the re-organization of these "seeds particles" evolves into a well-defined 3D sponge-like structure with heterogeneous diameters of $500 \mathrm{~nm}$ for larger particles and 50-100 nm for intermediate sizes (Figures 5e and 5f). Such results are expected to enhance the catalytic performances of the as-prepared materials. The increase of the reaction time leads to more $\mathrm{PtCl}_{6}^{2-}$ reduction, and the number of the elementary building blocks promptly increases. This number increase of the building blocks is logically accompanied by the size of the 3D microstructures constituted by 3D-interconnected nanoarrays (Figure 5h) leading to a framework at the surface of each carbon fiber (Figure $5 \mathrm{~g}$ ). These imaging results substantiate the metal loading obtained by TGA and the electrochemical data (ECSA, ORR). Indeed, both samples obtained at 0.5 and $2 \mathrm{~h}$ are very dense and this interconnection with aggregation of particles is well known to decrease the utilization efficiency of metal..$^{54,62}$ 


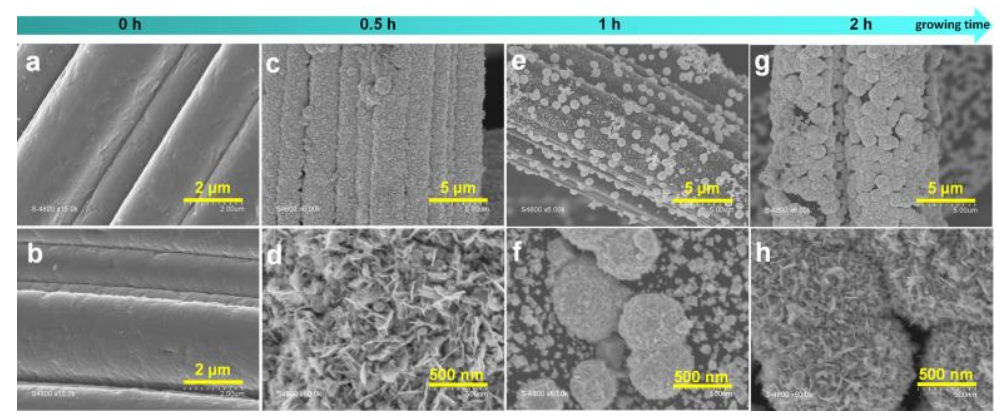

Figure 5. Close-view SEM/HRSEM micrographs of pristine RCF (a), bare ACF (b), and Pt metallic particles grown on ACF for the reaction times of $(\mathrm{c}, \mathrm{d}) 0.5 \mathrm{~h},(\mathrm{e}, \mathrm{f}) 1 \mathrm{~h}$, and $(\mathrm{g}, \mathrm{h}) 2 \mathrm{~h}$.

Additional Parameters Affecting the Formation of Anisotropic Pt Particles on Carbon Felt. The previous outcomes indicate the ability of our method to direct the synthesis towards different ACF@Pt electrodes with various surface behaviors. Next, the role of $\mathrm{PtCl}_{6}^{2-}$ concentration as precursor for the electrodeposition solution was interrogated by choosing a reaction time of $1 \mathrm{~h}$ as the best compromise. Table 2 summarizes the obtained data from physical and electrochemical characterizations. The experimental Pt loading are in agreement with TGA results while the overestimated Pt from CA measurement results from the explanation already given above. In addition, ICP analysis from representative samples of the concentrationdependant synthesis gives values of 2.0, 8.9 and 13.4 wt.\% for $\mathrm{C} 1, \mathrm{C} 3$ and $\mathrm{C} 5$, respectively. The obtained metal loading of 13.4 wt.\% for C5 (ACF@PT_CA-T1) substantiates the TGA outcome. $\mathrm{CVs}$ in $\mathrm{KOH}$ (Figure 6a, $\mathrm{pH}$ 13) and PBS (Figure $\mathrm{S6a}, \mathrm{pH}$ 7) indicate an increase of the hydrogen region current density, corroborated by the ECSA (Table 2 and Figure S6b: the description of the method used for ECSA evaluation is reported within the Supplementary Information (Figure S7)). After normalization with Pt content, SECSA is 6,10 and $9 \mathrm{~m}^{2} \mathrm{~g}^{-1}$ for C1, C3 and C5 samples, respectively. Figures 6b and 6c display ORR polarizations, pointing out 
the best performance achieved by the material obtained at $5 \mathrm{mM}$ within the potential window of interest in FCs (E $\geq 0.8 \mathrm{~V}$ vs. RHE). SEM micrographs depicted in Figures 6d-f for concentrations of 1,3 and $5 \mathrm{mM}$ show that the size and coverage of ACF by Pt particulates depend strongly on the input, i.e. $\mathrm{Pt}^{\mathrm{IV}}$ species in the synthesis reactor. The effect of low concentration is similar to those previously observed in Figure 5. The swift reduction of $\mathrm{Pt}^{\mathrm{IV}}$ on the entire fiber surface leads to a thin-film that further acts as active sites for the anisotropic growth Pt clusters into larger particulates. Larger amount $(7 \mathrm{mM})$ results in the formation of bigger arrays, thus decreasing the utilization efficiency of the catalyst. Hence, the accessibility of $\mathrm{O}_{2}$ molecules to all $\mathrm{Pt}$ within each particle is limited.

Table 2. Summarized results from physicochemical and electrochemical characterizations by electrodeposition (chronoamperometry: CA), ICP, TGA, XRD and CV for materials at different inputs of $\mathrm{PtCl}_{6}^{2-}$ (RCF and ACF are blanks). n.d.: not determined.

\begin{tabular}{|c|c|c|c|c|c|c|c|c|c|}
\hline \multirow[b]{2}{*}{ Entry } & \multirow{2}{*}{$\begin{array}{c}S_{\mathrm{g}} \\
\left(\mathrm{cm}^{2}\right)\end{array}$} & \multirow{2}{*}{$\begin{array}{c}\text { Theory } \\
\begin{array}{c}\mathrm{Pt} \\
\text { (wt.\%) }\end{array}\end{array}$} & \multirow{2}{*}{ 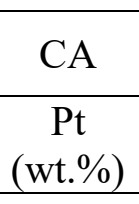 } & \multirow{2}{*}{$\begin{array}{c}\text { ICP } \\
\begin{array}{c}\mathrm{Pt} \\
\text { (wt.\%) }\end{array}\end{array}$} & \multirow{2}{*}{ 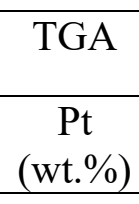 } & \multicolumn{2}{|c|}{ XRD } & \multicolumn{2}{|c|}{ CV: Pt ECSA $\left(\mathrm{cm}^{2}\right)$} \\
\hline & & & & & & $\begin{array}{l}a_{\mathrm{Pt}} \\
(\AA)\end{array}$ & $\begin{array}{c}L_{\mathrm{V}} \\
(\mathrm{nm})\end{array}$ & $\mathrm{KOH}$ & PBS \\
\hline $\mathrm{ACF}$ & 3.9 & 0 & - & - & 0 & - & - & - & - \\
\hline $\mathrm{C} 1$ & 3.9 & 4.3 & 1.6 & 2.0 & 2.9 & 3.95 & 11.6 & $\begin{array}{l}100.0 \\
\pm 3.2\end{array}$ & $\begin{array}{r}18.0 \\
\pm 0.9\end{array}$ \\
\hline $\mathrm{C} 2$ & 3.9 & 7.2 & 2.8 & \multicolumn{4}{|c|}{ n.d. } & $\begin{array}{c}451.4 \\
\pm 16.1 \\
\end{array}$ & $\begin{array}{l}369.5 \\
\pm 9.1 \\
\end{array}$ \\
\hline $\mathrm{C} 3$ & 3.9 & 8.2 & 10.4 & 8.9 & 8.6 & 3.95 & 10.8 & $\begin{array}{l}537.2 \\
\pm 4.8\end{array}$ & $\begin{array}{r}293.5 \\
\pm 10.6 \\
\end{array}$ \\
\hline C5 & 3.9 & 19.5 & 12.8 & 13.4 & 13.0 & 3.95 & 9.3 & $\begin{array}{l}825.1 \\
\pm 8.7\end{array}$ & $\begin{array}{c}454.8 \\
\pm 11.3\end{array}$ \\
\hline C7 & 3.9 & 27.3 & 45.7 & \multicolumn{4}{|c|}{ n.d. } & $\begin{array}{c}876.8 \\
\pm 13.6\end{array}$ & $\begin{array}{r}331.7 \\
\pm 10.4 \\
\end{array}$ \\
\hline
\end{tabular}



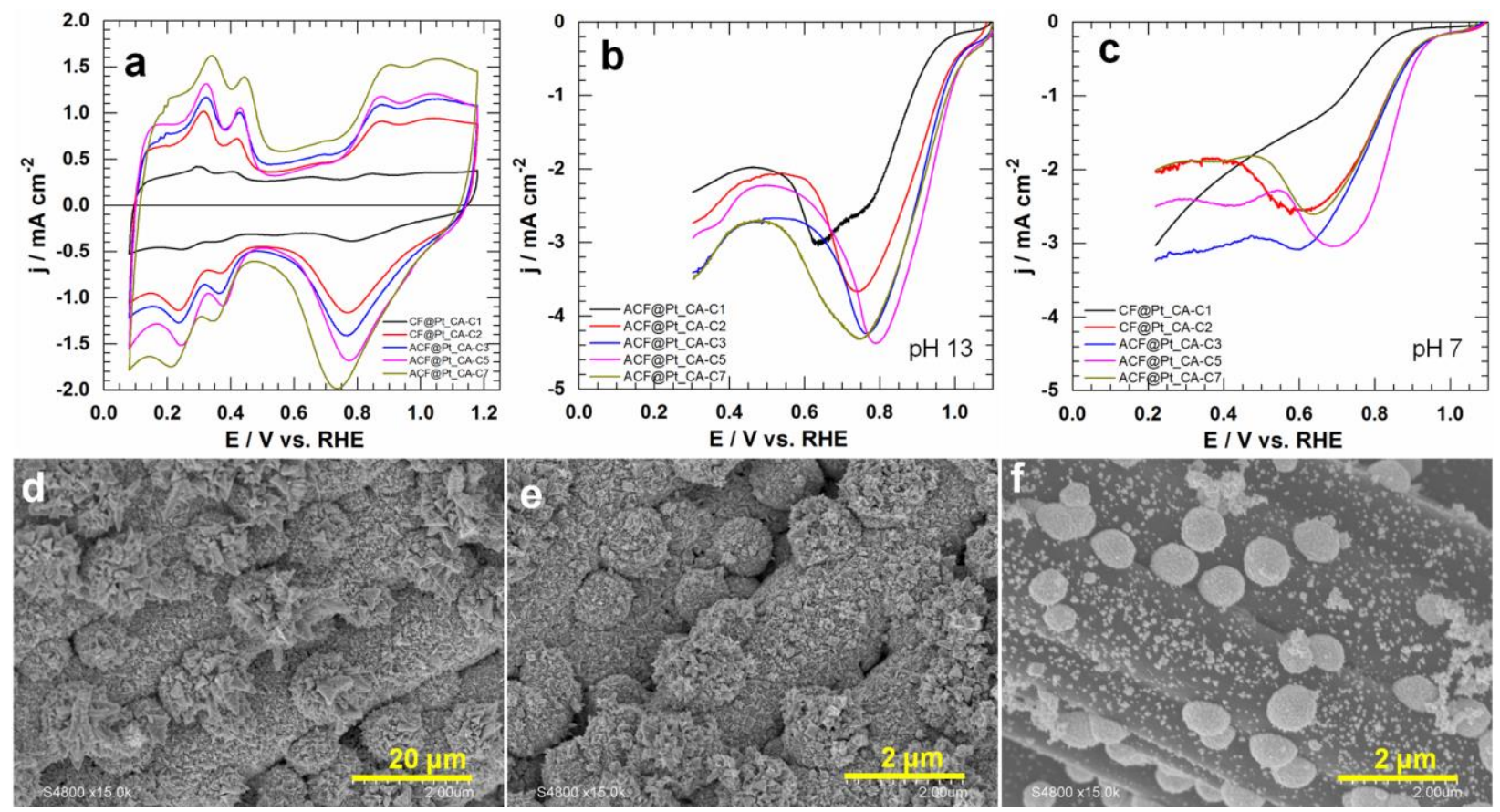

Figure 6. Characterization and performance of as-synthesized materials by the method of CA (ACF@Pt_CA) under $\mathrm{N}_{2}$ atmosphere for different precursor concentrations $(1,3,5$, and $7 \mathrm{mM}$ ).

(a) Steady-state CVs recorded at $5 \mathrm{mV} \mathrm{s}^{-1}$ in $\mathrm{N}_{2}$-saturated $0.1 \mathrm{M} \mathrm{KOH}$ aqueous solution $(\mathrm{pH}$

13). iR-uncorrected ORR polarization curves recorded at $5 \mathrm{mV} \mathrm{s}^{-1}$ : (b) $\mathrm{O}_{2}$-saturated $0.1 \mathrm{M}$ $\mathrm{KOH},(\mathrm{c}) \mathrm{O}_{2}$-saturated $50 \mathrm{mM}$ PBS aqueous solution ( $\mathrm{pH}$ 7). Close-view SEM micrographs of Pt particles growth on ACF for the precursor concentration of: (d) $1 \mathrm{mM}$, (e) $3 \mathrm{mM}$, and (f) $5 \mathrm{mM}$.

\section{Electrochemical Performances towards 4-electron ORR, HER and MFC.}

Determination of the depth of ORR. Before integrating the home-made ACF@Pt materials as airbreathing cathode in MCF application, it is highly important to design electroanalytical experiments to evaluate the amount of possible $\mathrm{H}_{2} \mathrm{O}_{2}$ as an incomplete reaction product since the classical rotating ring-disk electrode (RRDE) setup $^{63,64}$ is not useful herein. Owing to the presence of Pt particulates, we hypothesize that the event of ORR using ACF@Pt electrode 
produces only $\mathrm{OH}^{-}$at $\mathrm{pH} 13\left(\mathrm{O}_{2}+2 \mathrm{H}_{2} \mathrm{O}+4 \mathrm{e}^{-} \rightarrow 4 \mathrm{OH}^{-}\right)$, which is the maximum faradaic yield (exchanged number of electrons of 4). Indeed, the production of stable $\mathrm{HO}_{2}^{-}$(net reaction: $\mathrm{O}_{2}+$ $2 \mathrm{HO}^{-} \rightarrow 2 \mathrm{HO}_{2}^{-}$) within alkaline aqueous environments where the hydroperoxide ion $\mathrm{HO}_{2}^{-}$is the conjugated base of $\mathrm{H}_{2} \mathrm{O}_{2}$ is well-known $\left(\mathrm{pKa}\left(\mathrm{H}_{2} \mathrm{O}_{2} / \mathrm{HO}_{2}{ }^{-}\right)=11.75\right.$ at $\left.25{ }^{\circ} \mathrm{C}\right){ }^{65-67}$ Thus, within our conditions, any produced $\mathrm{H}_{2} \mathrm{O}_{2}$ from incomplete ORR in a 2-electron process $\left(\mathrm{O}_{2}+\mathrm{H}_{2} \mathrm{O}+\right.$ $2 \mathrm{e}^{-} \rightarrow \mathrm{OH}^{-}+\mathrm{HO}_{2}^{-}$) is in the form of $\mathrm{HO}_{2}^{-}$. As investigated by LSV above, the resulting current for differing electrodes (RCF, ACF and $\mathrm{ACF} @ \mathrm{Pt}$ ) allow an accurate determination of the efficiency of oxygen reduction. Hence, we next sought to screen the reaction by running $1 \mathrm{~h} \mathrm{CA}$ while recording the current $(I)$ followed by substrate analysis. To this end, we turned out our electroanalytical tool to enable the detection of "trace product" by UV-Vis assays where collected samples were acidified toward $\mathrm{pH} 3.5$, and the resulting $\mathrm{H}_{2} \mathrm{O}_{2}$ was quantified spectrophotometrically via a calibration curve obtained from standard solutions. After the CA, the $I$ vs. $t$ behavior is integrated to determine the involved charge $(Q)$, and then used to calculate the intermediate $\mathrm{HO}_{2}{ }^{-}$concentration. Figure 7a compares the reduction current to the quantity of electricity resulting from the reaction at each electrode for each applied electrode potential $\left(E_{\text {appl }}\right)$, which was chosen based on the preliminary LSV curves (Figure $\left.3 b\right)$. The current is quite constant, highlighting the good stability of the as-fabricated electrodes. The entire analyzed data are reported within Table S1. Figure $7 \mathrm{~b}$ shows the as-quantified $\mathrm{H}_{2} \mathrm{O}_{2}$ from UV-Vis assays where negligible intermediate is detectible on $\mathrm{ACF} @ \mathrm{Pt}$ material, thus underpinning the conclusion that ORR is performed in a 4-electron process. The durability of electrodes in strong corrosive and degrading alkaline conditions is one of the major issues in designing efficient electrocatalysts. ${ }^{40}$ Thereof, we sought to evaluate the impact of the electrochemical treatment (fixed potential of 0.8 $\mathrm{V}$ vs. RHE in $\mathrm{O}_{2}$-saturated $0.1 \mathrm{M} \mathrm{KOH}$ for $3 \mathrm{~h}$ ) on the evolution of the obtained ACF@Pt 
material. Figure 7c shows the post-reaction SEM images for different areas of the sample, focused on small particles (more sensitive to a morphology change). No significant morphology modification is noticed, fully supported by the recorded amperometric $I$ vs. $t$ curve that does not show any current decay (the first $60 \mathrm{~min}$ is depicted within Figure 7a). Taken together, all these findings endorse the good electrochemical stability of the fabricated ACF@Pt.
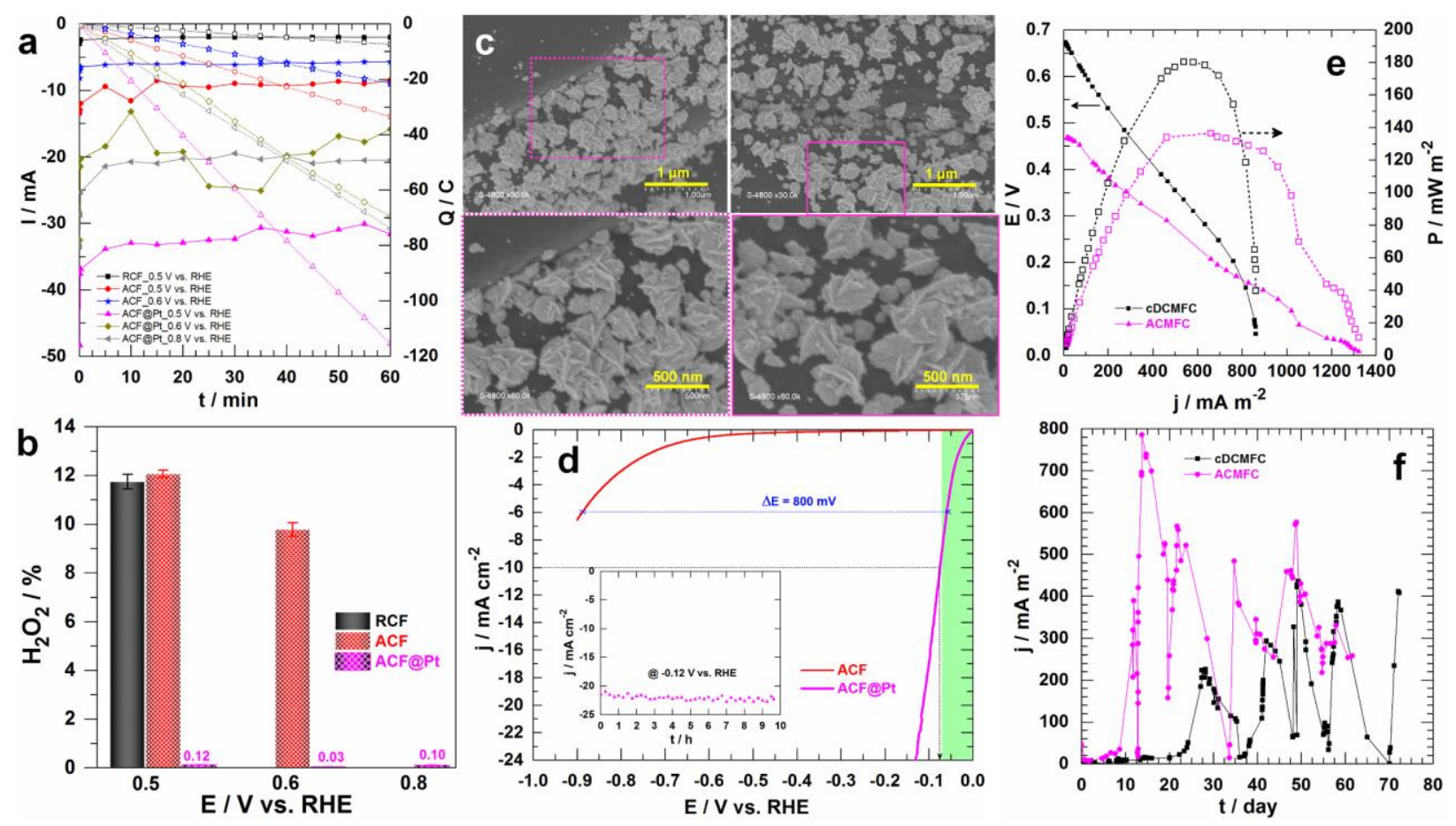

Figure 7. (a) Behavior of $I$ (left $y$-axis: filled symbols) and $Q$ (right $y$-axis: opened symbols) during $\mathrm{CA}$ in $\mathrm{O}_{2}$-saturated $0.1 \mathrm{M} \mathrm{KOH}$ aqueous solution on different electrode materials and at various electrode potentials. (b) Potential-dependent production of $\mathrm{H}_{2} \mathrm{O}_{2}$ production from incomplete ORR, as-quantified from UV-Vis assays (note: $\mathrm{HO}_{2}{ }^{-}$was converted into $\mathrm{H}_{2} \mathrm{O}_{2}$ before 3 assays). (c) SEM micrographs of aged ACF@Pt material after 3 h of electrochemical durability test $\left(\mathrm{O}_{2}\right.$-saturated $0.1 \mathrm{M} \mathrm{KOH}$ solution at $0.8 \mathrm{~V}$ vs. RHE). (d) iR-free HER polarization curves recorded at $5 \mathrm{mV} \mathrm{s}^{-1}$ on ACF and ACF@Pt in $\mathrm{N}_{2}$-saturated $0.1 \mathrm{M} \mathrm{KOH}$ aqueous solution: inset 
shows the durability of ACF@Pt at -0.12 V vs RHE. (e) Fuel cell polarization curves (iRuncorrected): Nafion ${ }^{\circledR} 115$ PEM separated both sides; anodic part (anaerobic: garden compost leachate + acetate). cDCMFC: $20 \mathrm{mM}$ potassium ferricyanide solution and stainless steel cathode. ACMFC: ACF@Pt air-cathode. (f) Performance of ACMFC and cDCMFC exhibiting by current generation at load resistance of $1 \mathrm{k} \Omega$ connected to the MFC: a fresh fuel is added at each current minimum.

Performance towards HER. Next, we aimed to study the newly described ACF@Pt as electrode materials for another model reaction in alkaline media, HER, that is very important for water splitting to supply PEMFCs by $\mathrm{H}_{2}$, which is also a critical chemical feedstock in the modern industry used in the synthesis of ammonia for fertilizer and petroleum refining. ${ }^{52}$ Figure $7 \mathrm{~d}$ displays LSV curves in $0.1 \mathrm{M} \mathrm{KOH}$ for ACF@Pt electrode material where the reaction $\left(2 \mathrm{H}_{2} \mathrm{O}+\right.$ $2 \mathrm{e}^{-} \rightarrow \mathrm{H}_{2}+2 \mathrm{OH}^{-}$) starts without any overpotential at $0 \mathrm{~V}$ vs. RHE while ACF used as a control electrode exhibits a large overpotential of $400 \mathrm{mV}$. Only overpotentials of 55 and $75 \mathrm{mV}$ are needed to reach current densities $j$ of -5 and $-10 \mathrm{~mA} \mathrm{~cm}^{-2}$ compared to benchmark materials in alkaline medium. ${ }^{11,68-71}$ It is worth of mentioning that the current density of $|j|=10 \mathrm{~mA} \mathrm{~cm}{ }^{-2}$ is the most used relevant metric for HER catalysts evaluation in acidic media and due to the reduced kinetics in basic solutions, $|j|=5 \mathrm{~mA} \mathrm{~cm}^{-2}$ is commonly used in alkaline solutions. ${ }^{70-73}$ Importantly, ACF@Pt material exhibits exceptional durability evaluated by either long-term CA to mimic the practical operation of the catalyst (inset of Figure 7d). Furthermore, the developed strategy (to grow Pt particulates directly on high surface area and scalable electrodes with porous 3D structure that can be directly used for the tests) can be readily scaled-up for the large-scale 
catalyst elaboration to be integrated into hydrogen generation devices (solar-fuel devices, electrolyzer based on water or alcohols in basic solutions).

Performance towards MFC. Finally, we tested the cell performance employing the assynthesized ACF@Pt as an air-breathing cathode and a garden compost electrode as bioanode, respectively (ACMFC). Figure 7e depicts the polarization curves in terms of cell voltage $(E)$ and out power density $(P)$ where cDCMFC (classical) was used as reference, both powered by the garden compost leachate. The recorded OCV (0.67 and $0.47 \mathrm{~V}$ for cDCMFC and ACMFC, respectively), $P$ (180 and $140 \mathrm{~mW} \mathrm{~m}^{-2}$ for cDCMFC and ACMFC, respectively) and maximum current density $\left(j_{\mathrm{sc}}\right)$ are comparable to relevant reported values within the literature for biological or abiotic (metal-based) cathodes. ${ }^{13-15,21,23,27}$ Figure $7 f$ shows the long-term operation of both systems in current generation. To avoid limitation in cDCMFC, it was necessary to add fresh ferricyanide solution in cathodic part (to maintain power generation) while the design of ACMFC system eliminates the continuous supply. Minima indicate the depletion of fuel and the decrease of $j$ over time could also be attributed to a thicker biofilm formation on the anode surface that increases proton transfer resistance and inhibit substrate diffusion. ${ }^{74-76}$ It should be noted that, a fresh fuel is added to recover the current when a minimum is reached. The small current within the first days corresponds to the formation of an electroactive biofilm on the anode surface. ${ }^{26,27,75}$ Then, only 1 week is needed for ACMFC to produce high current density while it takes almost 3 weeks for cDCMFC to generate power, thus indicating that the efficient formation of biofilm is linked to the air-breathing cathode, the main reason is still unknown. The main difference with previous garden compost $\mathrm{MFCs}^{24,26-28}$ is the suppression of a preliminary step to develop an electroactive biofilm. Therefore, it would be an advantage for application in a real system. It is worth of noting that the polarization curves within Figure $7 \mathrm{e}$ were collected 
when the current density reached its maximum value at first cycle i.e. at $49^{\text {th }}$ day for cDCMFC and at $13^{\text {th }}$ day for ACMFC.

\section{CONCLUSION}

In summary, this research shows the feasibility of simple decoration of carbon felt by platinum as multifunctional electrode materials for oxygen reduction reaction (ORR at $\mathrm{pH} 13$ and 7), hydrogen evolution reaction (HER at $\mathrm{pH}$ 13) and air-breathing cathode microbial fuel cell (ACMFC) associated with a garden compost bioanode. Up to now, the overwhelming majority of methodologies available to material scientists for the production of catalysts do not employ the elegant approach of growing particulates directly onto usable high surface area and electrical conducting materials with a three-dimensional (3D) structure. Within this contributing report on such novel class of electrode materials, we demonstrated herein that not only the direct formation of $3 \mathrm{D}$ and anisotropic Pt microstructures at the surface of carbon felt material is feasible but can also be used as an effective tool to fabricate high-performance electrocatalysts. The performance of the garden compost based ACMFC was demonstrated to be better than its equivalent classical double chamber (cDCMFC), attributable to the particular morphology and intimate metalsupport contact. By fine-tuning the experimental conditions, we were able to regulate the particles growth. It generates Pt nanoarrays (each particulate of $\sim 500 \mathrm{~nm}$ is composed of various 40-60 nm ultrathin 3D particles as elementary building blocks) having various roughness and distinguished electrocatalytic properties (ORR starts at $E_{\text {onset }} \sim 1.1 \mathrm{~V}$ vs. RHE in a quasi-4electron process with hydrogen peroxide $<0.1 \%$, HER reaches $-10 \mathrm{~mA} \mathrm{~cm}{ }^{-2}$ for only $75 \mathrm{mV}$ overpotential). The presented approach enables bypassing the use of any Nafion binder during 
the electrode preparation and minimizes the particle detachment during the reaction, which was fully supported by the stability and post-reaction analysis by scanning electron microscopy. Since the metal particles are directly assembled onto the electrode surface, there is no need to prepare a catalytic ink, thus allowing the simplification of the electrode-assembly process. Owing to these unique outcomes, it is believed that the developed idea will offer a new strategic approach for simplifying the design of electrodes to achieve superior performance.

\section{ASSOCIATED CONTENT}

Supporting Information. The following files are available free of charge.

Table S1 for electroanalytical study of $\mathrm{O}_{2}$ reduction, described method for ECSA evaluation and additional Figures S1-S7 such as contact angle measurement, EIS in $10 \mathrm{mM} \mathrm{K}_{3}\left[\mathrm{Fe}(\mathrm{CN})_{6}\right]+1 \mathrm{M}$ $\mathrm{KNO}_{3}$, XPS surveys, FTIR spectra, Cross-section SEM micrographs of ACF@Pt. (PDF)

\section{AUTHOR INFORMATION}

\section{Corresponding Author}

* C.I.: E-mail: christophe.innocent@univ-montp2.fr

* M.C.: E-mail: marc.cretin@umontpellier.fr

\section{Author Contributions}

The manuscript was written through contributions of all authors. All authors have given approval to the final version of the manuscript.

\section{Notes}


The authors declare no competing financial interest.

\section{ACKNOWLEDGMENT}

We acknowledge financial support from Indonesian government (RISTEKDIKTI, Indonesia), Institut Européen des Membranes (IEM) and Université de Montpellier (France).

\section{REFERENCES}

(1) Katsounaros, I.; Cherevko, S.; Zeradjanin, A. R.; Mayrhofer, K. J. J., Oxygen Electrochemistry as a Cornerstone for Sustainable Energy Conversion. Angew. Chem. Int. Ed. 2014, 53, 102-121.

(2) Bacon, F. T., Fuel Cells: Will they Soon become a Major Source of Electrical Energy? Nature 1960, 186, 589-592.

(3) Greeley, J.; Markovic, N. M., The road from animal electricity to green energy: combining experiment and theory in electrocatalysis. Energy Environ. Sci. 2012, 5, 9246-9256. (4) Yu, E. H.; Wang, X.; Krewer, U.; Li, L.; Scott, K., Direct oxidation alkaline fuel cells: from materials to systems. Energy Environ. Sci. 2012, 5, 5668-5680.

(5) Marchionni, A.; Bevilacqua, M.; Bianchini, C.; Chen, Y.-X.; Filippi, J.; Fornasiero, P.; Lavacchi, A.; Miller, H.; Wang, L.; Vizza, F., Electrooxidation of Ethylene Glycol and Glycerol on Pd-(Ni-Zn)/C Anodes in Direct Alcohol Fuel Cells. ChemSusChem 2013, 6, 518-528.

(6) Erable, B.; Féron, D.; Bergel, A., Microbial Catalysis of the Oxygen Reduction Reaction for Microbial Fuel Cells: A Review. ChemSusChem 2012, 5, 975-987.

(7) Higgins, S. R.; Lau, C.; Atanassov, P.; Minteer, S. D.; Cooney, M. J., Hybrid Biofuel Cell: Microbial Fuel Cell with an Enzymatic Air-Breathing Cathode. ACS Catal. 2011, 1, 994997.

(8) Liu, H.; Logan, B. E., Electricity Generation Using an Air-Cathode Single Chamber Microbial Fuel Cell in the Presence and Absence of a Proton Exchange Membrane. Environ. Sci. Technol. 2004, 38, 4040-4046.

(9) Southcott, M.; MacVittie, K.; Halamek, J.; Halamkova, L.; Jemison, W. D.; Lobel, R.; Katz, E., A pacemaker powered by an implantable biofuel cell operating under conditions 
mimicking the human blood circulatory system - battery not included. Phys. Chem. Chem. Phys. 2013, 15, 6278-6283.

(10) Milton, R. D.; Wu, F.; Lim, K.; Abdellaoui, S.; Hickey, D. P.; Minteer, S. D., Promiscuous Glucose Oxidase: Electrical Energy Conversion of Multiple Polysaccharides Spanning Starch and Dairy Milk. ACS Catal. 2015, 5, 7218-7225.

(11) Stamenkovic, V. R.; Strmcnik, D.; Lopes, P. P.; Markovic, N. M., Energy and fuels from electrochemical interfaces. Nat. Mater. 2017, 16, 57-69.

(12) Konda, S. K.; Amiri, M.; Chen, A., Photoassisted Deposition of Palladium Nanoparticles on Carbon Nitride for Efficient Oxygen Reduction. J. Phys. Chem. C 2016, 120, 14467-14473.

(13) Rismani-Yazdi, H.; Carver, S. M.; Christy, A. D.; Tuovinen, O. H., Cathodic limitations in microbial fuel cells: An overview. J. Power Sources 2008, 180, 683-694.

(14) Santoro, C.; Serov, A.; Stariha, L.; Kodali, M.; Gordon, J.; Babanova, S.; Bretschger, O.; Artyushkova, K.; Atanassov, P., Iron based catalysts from novel low-cost organic precursors for enhanced oxygen reduction reaction in neutral media microbial fuel cells. Energy Environ. Sci. 2016, $9,2346-2353$.

(15) Kodali, M.; Gokhale, R.; Santoro, C.; Serov, A.; Artyushkova, K.; Atanassov, P., High Performance Platinum Group Metal-Free Cathode Catalysts for Microbial Fuel Cell (MFC). J. Electrochem. Soc. 2017, 164, H3041-H3046.

(16) Pita, M.; Gutierrez-Sanchez, C.; Olea, D.; Velez, M.; Garcia-Diego, C.; Shleev, S.;

Fernandez, V. M.; De Lacey, A. L., High Redox Potential Cathode Based on Laccase Covalently Attached to Gold Electrode. J. Phys. Chem. C 2011, 115, 13420-13428.

(17) Mazurenko, I.; Monsalve, K.; Rouhana, J.; Parent, P.; Laffon, C.; Goff, A. L.; Szunerits, S.; Boukherroub, R.; Giudici-Orticoni, M.-T.; Mano, N.; Lojou, E., How the Intricate Interactions between Carbon Nanotubes and Two Bilirubin Oxidases Control Direct and Mediated O2 Reduction. ACS Appl. Mater. Interfaces. 2016, 8, 23074-23085.

(18) Logan, B. E.; Hamelers, B.; Rozendal, R.; Schröder, U.; Keller, J.; Freguia, S.; Aelterman, P.; Verstraete, W.; Rabaey, K., Microbial Fuel Cells: Methodology and Technology. Environ. Sci. Technol. 2006, 40, 5181-5192.

(19) Grattieri, M.; Suvira, M.; Hasan, K.; Minteer, S. D., Halotolerant extremophile bacteria from the Great Salt Lake for recycling pollutants in microbial fuel cells. J. Power Sources 2017, $356,310-318$. 
(20) Fornero, J. J.; Rosenbaum, M.; Angenent, L. T., Electric Power Generation from Municipal, Food, and Animal Wastewaters Using Microbial Fuel Cells. Electroanalysis 2010, $22,832-843$.

(21) Santoro, C.; Artyushkova, K.; Babanova, S.; Atanassov, P.; Ieropoulos, I.; Grattieri, M.; Cristiani, P.; Trasatti, S.; Li, B.; Schuler, A. J., Parameters characterization and optimization of activated carbon (AC) cathodes for microbial fuel cell application. Bioresour. Technol. 2014, 163, 54-63.

(22) Logan, B. E., MFCs for Wastewater Treatment. In Microbial Fuel Cells, Logan, B. E., Ed. John Wiley \& Sons, Inc.: Hoboken, NJ, USA, 2008, pp 146-161.

(23) Mateo-Ramírez, F.; Addi, H.; Hernández-Fernández, F. J.; Godínez, C.; Pérez de los Ríos, A.; Lotfi, E. M.; El Mahi, M.; Lozano Blanco, L. J., Air breathing cathode-microbial fuel cell with separator based on ionic liquid applied to slaughterhouse wastewater treatment and bioenergy production. J. Chem. Technol. Biotechnol. 2017, 92, 642-648.

(24) Cercado-Quezada, B.; Delia, M.-L.; Bergel, A., Testing various food-industry wastes for electricity production in microbial fuel cell. Bioresour. Technol. 2010, 101, 2748-2754.

(25) Yang, W.; Kim, K.-Y.; Saikaly, P. E.; Logan, B. E., The impact of new cathode materials relative to baseline performance of microbial fuel cells all with the same architecture and solution chemistry. Energy Environ. Sci. 2017, 10, 1025-1033.

(26) Parot, S.; Délia, M.-L.; Bergel, A., Acetate to enhance electrochemical activity of biofilms from garden compost. Electrochim. Acta 2008, 53, 2737-2742.

(27) Champavert, J.; Ben Rejeb, S.; Innocent, C.; Pontié, M., Microbial fuel cell based on Nitetra sulfonated phthalocyanine cathode and graphene modified bioanode. J. Electroanal. Chem. 2015, 757, 270-276.

(28) Oliot, M.; Etcheverry, L.; Bergel, A., Removable air-cathode to overcome cathode biofouling in microbial fuel cells. Bioresour. Technol. 2016, 221, 691-696.

(29) Cheng, T.-M.; Huang, T.-K.; Lin, H.-K.; Tung, S.-P.; Chen, Y.-L.; Lee, C.-Y.; Chiu, H.T., (110)-Exposed Gold Nanocoral Electrode as Low Onset Potential Selective Glucose Sensor. ACS Appl. Mater. Interfaces. 2010, 2, 2773-2780.

(30) Both Engel, A.; Bechelany, M.; Fontaine, O.; Cherifi, A.; Cornu, D.; Tingry, S., One-Pot Route to Gold Nanoparticles Embedded in Electrospun Carbon Fibers as an Efficient Catalyst Material for Hybrid Alkaline Glucose Biofuel Cells. ChemElectroChem 2016, 3, 629-637. 
(31) Holade, Y.; Hickey, D. P.; Minteer, S. D., Halide-regulated growth of electrocatalytic metal nanoparticles directly onto a carbon paper electrode. J. Mater. Chem. A 2016, 4, 1715417162.

(32) Le, T. X. H.; Esmilaire, R.; Drobek, M.; Bechelany, M.; Vallicari, C.; nguyen, d.-1.; Julbe, A.; Tingry, S.; Cretin, M., Design of novel Fuel Cell-Fenton system: a smart approach to zero energy depollution. J. Mater. Chem. A 2016, 4, 17686-17693.

(33) Negro, E.; Latsuzbaia, R.; Dieci, M.; Boshuizen, I.; Koper, G. J. M., Pt electrodeposited over carbon nano-networks grown on carbon paper as durable catalyst for PEM fuel cells. Appl. Catal. B: Env. 2015, 166-167, 155-165.

(34) Haile, S. M., Fuel cell materials and components. Acta Mater. 2003, 51, 5981-6000.

(35) Litster, S.; McLean, G., PEM fuel cell electrodes. J. Power Sources 2004, 130, 61-76.

(36) Wee, J.-H.; Lee, K.-Y.; Kim, S. H., Fabrication methods for low-Pt-loading electrocatalysts in proton exchange membrane fuel cell systems. J. Power Sources 2007, 165, 667-677.

(37) Kloke, A.; Köhler, C.; Zengerle, R.; Kerzenmacher, S., Porous Platinum Electrodes Fabricated by Cyclic Electrodeposition of PtCu Alloy: Application to Implantable Glucose Fuel Cells. J. Phys. Chem. C 2012, 116, 19689-19698.

(38) Both Engel, A.; Holade, Y.; Tingry, S.; Cherifi, A.; Cornu, D.; Servat, K.; Napporn, T. W.; Kokoh, K. B., Electrospun Carbon Fibers: Promising Electrode Material for Abiotic and Enzymatic Catalysis. J. Phys. Chem. C 2015, 119, 16724-16733.

(39) Holade, Y.; Canaff, C.; Poulin, S.; Napporn, T. W.; Servat, K.; Kokoh, K. B., High impact of the reducing agent on palladium nanomaterials: new insights from X-ray photoelectron spectroscopy and oxygen reduction reaction. $R S C A d v$. 2016, 6, 12627-12637.

(40) Holade, Y.; da Silva, R. G.; Servat, K.; Napporn, T. W.; Canaff, C.; De Andrade, A. R.; Kokoh, K. B., Facile synthesis of highly active and durable $\mathrm{PdM} / \mathrm{C}(\mathrm{M}=\mathrm{Fe}, \mathrm{Mn})$ nanocatalysts for the oxygen reduction reaction in an alkaline medium. J. Mater. Chem. A 2016, 4, 8337-8349. (41) Bonét-Maury, P., Compt. rend., 218, 117 (1944, Titrage photocolorimétrique de faibles quantités d'eau oxygénée. Compt. rend. 1944, 218, 117-119.

(42) Patterson, B. D.; MacRae, E. A.; Ferguson, I. B., Estimation of hydrogen peroxide in plant extracts using titanium(IV). Anal. Biochem. 1984, 139, 487-492. 
(43) Le, T. X. H.; Charmette, C.; Bechelany, M.; Cretin, M., Facile Preparation of Porous Carbon Cathode to Eliminate Paracetamol in Aqueous Medium Using Electro-Fenton System. Electrochim. Acta 2016, 188, 378-384.

(44) Holade, Y.; Yuan, M.; Milton, R. D.; Hickey, D. P.; Sugawara, A.; Peterbauer, C. K.; Haltrich, D.; Minteer, S. D., Rational Combination of Promiscuous Enzymes Yields a Versatile Enzymatic Fuel Cell with Improved Coulombic Efficiency. J. Electrochem. Soc. 2017, 164, H3073-H3082.

(45) Le, T. X. H.; Bechelany, M.; Lacour, S.; Oturan, N.; Oturan, M. A.; Cretin, M., High removal efficiency of dye pollutants by electron-Fenton process using a graphene based cathode. Carbon 2015, 94, 1003-1011.

(46) Kim, K. J.; Lee, S.-W.; Yim, T.; Kim, J.-G.; Choi, J. W.; Kim, J. H.; Park, M.-S.; Kim, Y.-J., A new strategy for integrating abundant oxygen functional groups into carbon felt electrode for vanadium redox flow batteries. Sci. Rep. 2014, 4, Article number: 6906.

(47) Holade, Y.; Morais, C.; Servat, K.; Napporn, T. W.; Kokoh, K. B., Enhancing the available specific surface area of carbon supports to boost the electroactivity of nanostructured $\mathrm{Pt}$ catalysts. Phys. Chem. Chem. Phys. 2014, 16, 25609-25620.

(48) Xiong, Y.; Chen, J.; Wiley, B.; Xia, Y.; Aloni, S.; Yin, Y., Understanding the Role of Oxidative Etching in the Polyol Synthesis of Pd Nanoparticles with Uniform Shape and Size. $J$. Am. Chem. Soc. 2005, 127, 7332-7333.

(49) Xiong, Y.; Cai, H.; Wiley, B. J.; Wang, J.; Kim, M. J.; Xia, Y., Synthesis and Mechanistic Study of Palladium Nanobars and Nanorods. J. Am. Chem. Soc. 2007, 129, 36653675 .

(50) Randles, J. E. B., A cathode ray polarograph. Part II.-The current-voltage curves. Trans. Faraday Soc. 1948, 44, 327-338.

(51) Bard, A. J.; Faulkner, L. R., Electrochemical Methods: Fundamentals and Applications. 2nd ed.; John Wiley \& Sons, Inc.: USA, 2001; p 850.

(52) Shi, Y.; Zhang, B., Recent advances in transition metal phosphide nanomaterials: synthesis and applications in hydrogen evolution reaction. Chem. Soc. Rev. 2016, 45, 1529-1541. (53) Holade, Y.; Tingry, S.; Servat, K.; Napporn, T.; Cornu, D.; Kokoh, K., Nanostructured Inorganic Materials at Work in Electrochemical Sensing and Biofuel Cells. Catalysts 2017, 7, 31. 
(54) Wieckowski, A.; Nørskov, J. K., Fuel Cell Science. John Wiley \& Sons, Inc.: Hoboken, NJ, USA, 2010; 10.1002/9780470630693p 216.

(55) Gasteiger, H. A.; Kocha, S. S.; Sompalli, B.; Wagner, F. T., Activity benchmarks and requirements for Pt, Pt-alloy, and non-Pt oxygen reduction catalysts for PEMFCs. Appl. Catal. B: Env. 2005, 56, 9-35.

(56) Zhang, C.; Hwang, S. Y.; Peng, Z., Size-dependent oxygen reduction property of octahedral Pt-Ni nanoparticle electrocatalysts. J. Mater. Chem. A 2014, 2, 19778-19787.

(57) Nesselberger, M.; Ashton, S.; Meier, J. C.; Katsounaros, I.; Mayrhofer, K. J. J.; Arenz, M., The Particle Size Effect on the Oxygen Reduction Reaction Activity of Pt Catalysts: Influence of Electrolyte and Relation to Single Crystal Models. J. Am. Chem. Soc. 2011, 133, 17428-17433.

(58) Ma, J.; Habrioux, A.; Pisarek, M.; Lewera, A.; Alonso-Vante, N., Induced electronic modification of Pt nanoparticles deposited onto graphitic domains of carbon materials by UV irradiation. Electrochem. Commun. 2013, 29, 12-16.

(59) Chatterjee, S. K., X-ray Diffraction: Its Theory and Applications. 2nd ed.; Prentice-Hall of India Pvt.Ltd: New Delhi, India, 2010.

(60) Suryanarayana, C.; Norton, M. G., X-Ray Diffraction, A Pratical Approach. Plenum Publishing Corporation: New York, 1998; p 292.

(61) Wasserman, H. J.; Vermaak, J. S., On the determination of the surface stress of copper and platinum. Surf. Sci. 1972, 32, 168-174.

(62) Wieckowski, A.; Savinova, E. R.; Vayenas, C. G., Catalysis and Electrocatalysis at Nanoparticle Surfaces. Marcel Dekker, Inc.: New York, USA, 2003; p 970.

(63) Pleskov, Y. V.; Filinovskii, V. Y., The Rotating Disc Electrode. Consultants Bureau: New York, USA, 1976.

(64) Xing, W.; Yin, G.; Zhang, J., Rotating Electrode Methods and Oxygen Reduction Electrocatalysts. 1 ed.; Elsevier Science and Technology: Poland, 2014; p 322.

(65) Campos-Martin, J. M.; Blanco-Brieva, G.; Fierro, J. L. G., Hydrogen Peroxide Synthesis: An Outlook beyond the Anthraquinone Process. Angew. Chem. Int. Ed. 2006, 45, 6962-6984.

(66) Brillas, E.; Alcaide, F.; Cabot, P.-L. s., A small-scale flow alkaline fuel cell for on-site production of hydrogen peroxide. Electrochim. Acta 2002, 48, 331-340. 
(67) Oloman, C.; Watkinson, A. P., Hydrogen peroxide production in trickle-bed electrochemical reactors. J. Appl. Electrochem. 1979, 9, 117-123.

(68) Zhang, J.; Wang, T.; Liu, P.; Liu, S.; Dong, R.; Zhuang, X.; Chen, M.; Feng, X., Engineering water dissociation sites in MoS2 nanosheets for accelerated electrocatalytic hydrogen production. Energy Environ. Sci. 2016, 9, 2789-2793.

(69) Durst, J.; Siebel, A.; Simon, C.; Hasche, F.; Herranz, J.; Gasteiger, H. A., New insights into the electrochemical hydrogen oxidation and evolution reaction mechanism. Energy Environ. Sci. 2014, 7, 2255-2260.

(70) Subbaraman, R.; Tripkovic, D.; Chang, K.-C.; Strmcnik, D.; Paulikas, A. P.; Hirunsit, P.; Chan, M.; Greeley, J.; Stamenkovic, V.; Markovic, N. M., Trends in activity for the water electrolyser reactions on 3d M(Ni,Co,Fe,Mn) hydr(oxy)oxide catalysts. Nat. Mater. 2012, 11, $550-557$.

(71) Luo, J.; Im, J.-H.; Mayer, M. T.; Schreier, M.; Nazeeruddin, M. K.; Park, N.-G.; Tilley, S. D.; Fan, H. J.; Grätzel, M., Water photolysis at $12.3 \%$ efficiency via perovskite photovoltaics and Earth-abundant catalysts. Science 2014, 345, 1593-1596.

(72) Zou, X.; Zhang, Y., Noble metal-free hydrogen evolution catalysts for water splitting. Chem. Soc. Rev. 2015, 44, 5148-5180.

(73) Benck, J. D.; Hellstern, T. R.; Kibsgaard, J.; Chakthranont, P.; Jaramillo, T. F., Catalyzing the Hydrogen Evolution Reaction (HER) with Molybdenum Sulfide Nanomaterials. ACS Catal. 2014, 4, 3957-3971.

(74) Santoro, C.; Lei, Y.; Li, B.; Cristiani, P., Power generation from wastewater using single chamber microbial fuel cells (MFCs) with platinum-free cathodes and pre-colonized anodes. Biochem. Eng. J. 2012, 62, 8-16.

(75) Nercessian, O.; Parot, S.; Délia, M.-L.; Bergel, A.; Achouak, W., Harvesting Electricity with Geobacter bremensis Isolated from Compost. PLOS ONE 2012, 7, e34216.

(76) Singh, S.; Modi, A.; Verma, N., Enhanced power generation using a novel polymercoated nanoparticles dispersed-carbon micro-nanofibers-based air-cathode in a membrane-less single chamber microbial fuel cell. Int. J. Hydrogen Energy 2016, 41, 1237-1247. 
Table of Contents/Abstract Graphic (TOC)

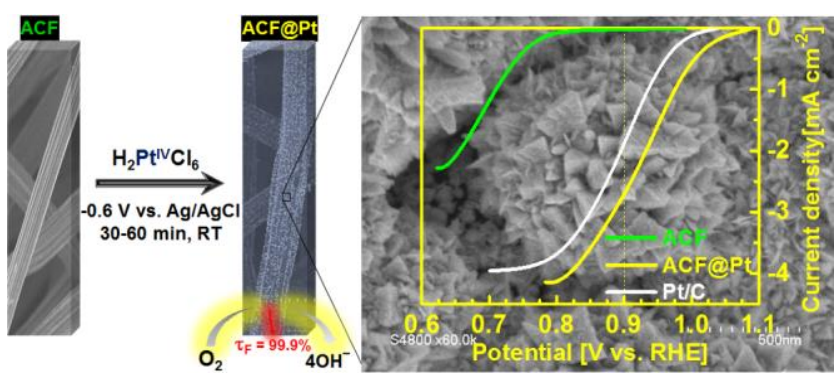

